Prepared in cooperation with the San Francisco Public Utilities Commission

\title{
Storage Capacity and Sedimentation Characteristics of the San Antonio Reservoir, California, 2018
}

Scientific Investigations Report 2019-5151

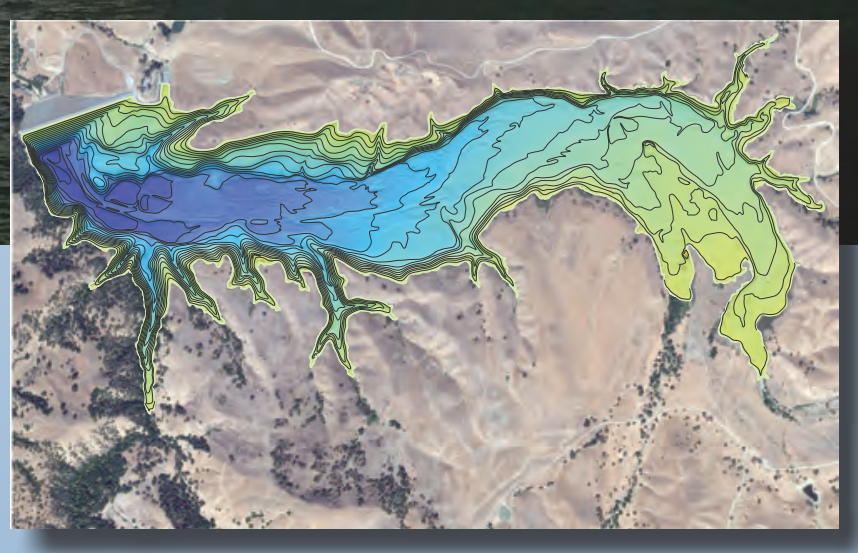

U.S. Department of the Interior U.S. Geological Survey 
Cover: San Antonio Reservior, Calfiornia; photograph taken by Mathieu D. Marineau, April 16, 2018.

Front Inset: Bathymetry and contour lines of San Antonio Reservoir, California. 


\section{Storage Capacity and Sedimentation Characteristics of the San Antonio Reservoir, California, 2018}

By Mathieu D. Marineau, Scott A. Wright, and Joan V. Lopez

Prepared in cooperation with the San Francisco Public Utilities Commission

Scientific Investigations Report 2019-5151 


\title{
U.S. Department of the Interior DAVID BERNHARDT, Secretary
}

\author{
U.S. Geological Survey \\ James F. Reilly II, Director
}

\section{U.S. Geological Survey, Reston, Virginia: 2020}

For more information on the USGS - the Federal source for science about the Earth, its natural and living resources, natural hazards, and the environment-visit https://www.usgs.gov or call 1-888-ASK-USGS.

For an overview of USGS information products, including maps, imagery, and publications, visit https://store.usgs.gov.

Any use of trade, firm, or product names is for descriptive purposes only and does not imply endorsement by the U.S. Government.

Although this information product, for the most part, is in the public domain, it also may contain copyrighted materials as noted in the text. Permission to reproduce copyrighted items must be secured from the copyright owner.

Suggested citation:

Marineau, M.D., Wright, S.A, and Lopez, J.V., 2020, Storage capacity and sedimentation characteristics of the San Antonio Reservoir, California, 2018: U.S. Geological Survey Scientific Investigations Report 2019-5151, 34 p., https://doi.org/10.3133/sir20195151.

Associated data for this publication:

Marineau, M.D., Wright, S.A., Lopez, J.V., 2019, Bathymetry, stage-area, and stage-volume tables for the San Antonio Reservoir, California, 2018: U.S. Geological Survey data release, https://doi.org/10.5066/P9KC9DU8. 


\section{Contents}

Abstract

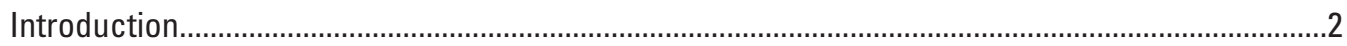

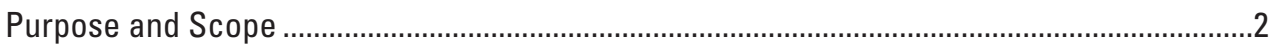

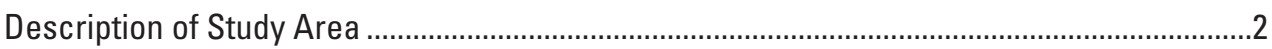

Vertical Datums and Previous Reservoir Surveys......................................................................

Data and Sample Collection...............................................................................................

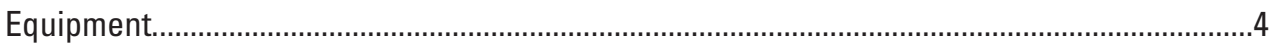

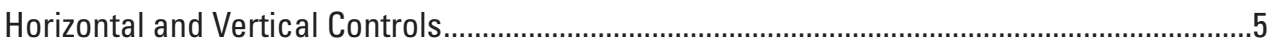

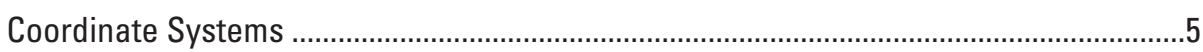

Orthometric Height Conversion ..............................................................................

Monumented Benchmarks..........................................................................................

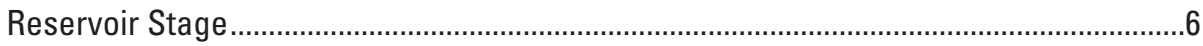

Bathymetric and Topographic Survey ..........................................................................

Bathymetric Data Collection Using Multibeam ...........................................................

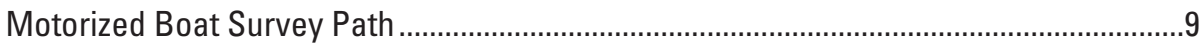

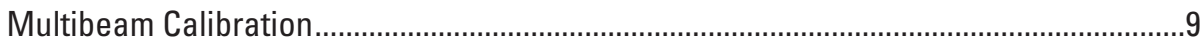

Sound-Speed Profiles ............................................................................................ 10

Topographic Data Collection Using Terrestrial Light Detection and Ranging and Global Navigation Satellite System Ground-Survey Methods.............................10

Real-Time Multibeam, Sound Speed, and Terrestrial Light Detection and Ranging Integration ..............................................................................................10

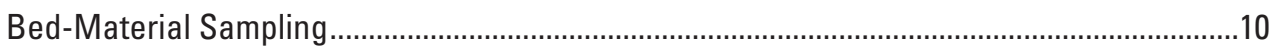

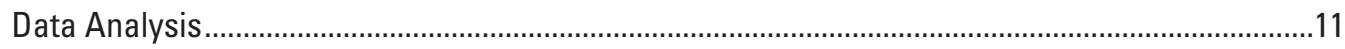

Shallow-Water Survey, Spillway Elevation, and Shoreline Digitization ...................................11

Sound-Speed Corrections ................................................................................................ 11

Digital Elevation Model Development ..............................................................................

Multibeam Indirect Depth Check ................................................................................11

Bed-Material Sample Preparation and Particle-Size Analysis................................................13

Particle-Size Distribution Using a Laser Diffraction Particle-Size Analyzer ..................13

Samples Containing Coarse Material..............................................................................13

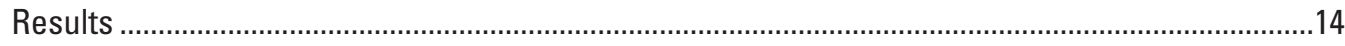

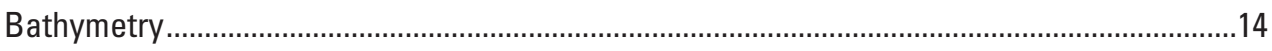

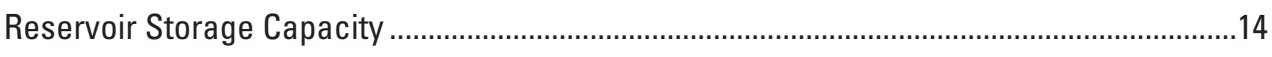

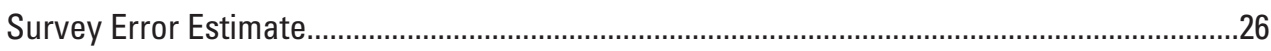

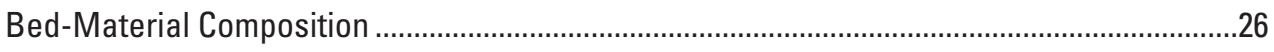

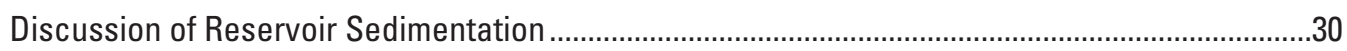

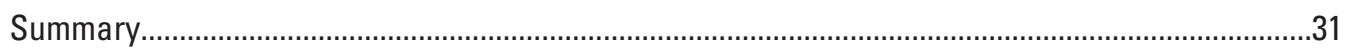

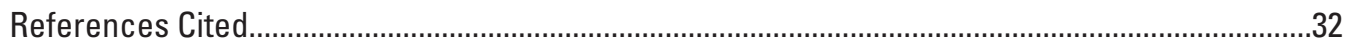

Glossary 


\section{Figures}

1. Map showing the San Antonio Reservoir and Watershed, California. .3

2. Photograph showing spillway at the San Antonio Reservoir, California.

3. Graph showing reservoir stage recorded and water-surface elevation measurements April 16-20, 2018, San Antonio Reservoir, California..

4. Map showing the boat tracks, topographic survey paths at San Antonio Creek delta, and locations of bed-material samples and sound-speed profiles, San Antonio Reservoir, California, 2018.

5. Graph showing examples of 10 sound-speed profiles collected during the April 16-20, 2018, survey of San Antonio Reservoir, California.

6. Graph showing bed elevation derived from depths measured using the soundspeed profiler and bed-material sampler in relation to bed elevation derived from the digital elevation model of the San Antonio Reservoir, California, 2018.

7. Contour map showing bathymetry and topography, based on the April 2018 survey, and median grain size bed material at sampled points, San Antonio Reservoir, California.

8. As-built construction drawings showing a cross-sectional profile of intake pipelines, a three-dimensional oblique view of sonar point-cloud image of intake structure, and a cross-sectional profile cut from sonar point-cloud data showing approximate locations of intakes and bed elevation over Intake \#1, San Antonio Reservoir, California, 2018.

9. Graphs showing stage-capacity curves for 1965 and 2018 with live storage capacity above Intake \#2 indicated, and stage-surface area curve for 2018, San Antonio Reservoir, California.

10. Graphical summary of cumulative particle-size distributions of bedmaterial samples collected during the April 2018 survey of the San Antonio Reservoir, California .

11. Graph showing longitudinal profiles of bed elevation, as extracted from the 2018 digital elevation model, along the historical (1960) San Antonio Creek centerline, and median particle size bed material from samples projected to the centerline, San Antonio Reservoir, California

\section{Tables}

1. Differences between published elevation and 2018 surveyed elevation for monumented benchmarks used for vertical control checks in the April 2018 bathymetric survey of San Antonio Reservoir, California.

2. Rating table for surface area of the San Antonio Reservoir, California, 2018. ................17

3. Rating table for storage capacity of the San Antonio Reservoir, California, 2018...........21

4. Summary of elevation and reservoir storage capacity above each intake, San Antonio Reservoir, California, 2018.

5. Bed-material samples data including location, depth, and mass, San Antonio Reservoir, California

6. Bed-material samples particle-size distribution data, San Antonio Reservoir, California 


\section{Conversion Factors}

Inch/Pound to International System of Units

\begin{tabular}{lcl}
\hline \multicolumn{1}{c}{ Multiply } & By & \multicolumn{1}{c}{ To obtain } \\
\hline inch (in.) & Length & \\
inch (in) & 2.54 & centimeter $(\mathrm{cm})$ \\
foot (ft) & 254 & millimeter $(\mathrm{mm})$ \\
mile (mi) & 0.3048 & meter $(\mathrm{m})$ \\
\hline & 1.609 & kilometer $(\mathrm{km})$ \\
\hline acre & Area & square meter $\left(\mathrm{m}^{2}\right)$ \\
square foot (ft $\left.{ }^{2}\right)$ & 4,047 & square meter $\left(\mathrm{m}^{2}\right)$ \\
square mile (mi $\left.{ }^{2}\right)$ & 0.09290 & square kilometer $\left(\mathrm{km}^{2}\right)$ \\
\hline & 2.590 & \\
\hline acre-foot (acre-ft) & Volume & cubic meter $\left(\mathrm{m}^{3}\right)$ \\
\hline & 1,233 & \\
\hline acre-foot per year (acre-ft/yr) & Flow rate & cubic meter per $\mathrm{year}\left(\mathrm{m}^{3} / \mathrm{yr}\right)$ \\
\hline & 1,233 & meter per second $(\mathrm{m} / \mathrm{s})$ \\
\hline foot per second (ft/s) & Velocity & meters per second, $\mathrm{m} / \mathrm{s}$ \\
\hline inches per second (in/s) & 0.3048 & \\
\hline
\end{tabular}

Temperature in degrees Fahrenheit $\left({ }^{\circ} \mathrm{F}\right)$ may be converted to degrees Celsius $\left({ }^{\circ} \mathrm{C}\right)$ as

$$
{ }^{\circ} \mathrm{C}=\left({ }^{\circ} \mathrm{F}-32\right) / 1.8 \text {. }
$$

\section{Datums}

Vertical coordinate information is referenced to the North American Vertical Datum of 1988 (NAVD 88) with conversions to the National Geodetic Vertical Datum of 1929 (NGVD 29) which was the standard datum at the time the dam was constructed. Datum shifts were calculated using the National Geodetic Survey VERTCON 2.0 model (available at https://www.ngs.noaa.gov/ TOOLS/Vertcon/vert_method.html). Applying the VERTCON 2.0 model at two locations (left dam abutment and spillway), the average vertical datum shift from NGVD 29 to NAVD 88 at the San Antonio Reservoir is estimated to be $+2.74 \mathrm{ft}$ (NGVD 29 elevation in feet plus $2.74 \mathrm{ft}$ equals NAVD 88 elevation in feet). For documentation of the VERTCON 2.0 model, see Milbert (1999).

Horizontal coordinate information is referenced to the North American Datum of 1983 (NAD 83) coordinates where the reference frame has been affixed to the North American plate [NAD 83(2011)], (National Geodetic Survey, 2017).

Elevation, as used in this report, refers to distance above the vertical datum. 


\section{Abbreviations}

$\begin{array}{ll}\text { BM } & \text { Benchmark } \\ \text { CDEC } & \text { California Data Exchange Center } \\ \text { CSDS } & \text { California Survey and Drafting Supply } \\ \text { DEM } & \text { Digital Elevation Model } \\ \text { D50 } & \text { Median grain size } \\ \text { D90 } & \text { 90th percentile grain size } \\ \text { GNSS } & \text { Global Navigation Satellite System } \\ \text { GNSS-RTN } & \text { Global Navigation Satellite System-Real Time Network } \\ \text { GPS } & \text { Global Positioning System } \\ \text { INS } & \text { Inertial Navigation System } \\ \text { LiDAR } & \text { Light Detection and Ranging } \\ \text { OINSY } & \text { Ouality Integrated Navigation System } \\ \text { OPS } & \text { Ouality Positioning Services } \\ \text { RWS } & \text { Hetch Hetchy Regional Water System } \\ \text { SFPUC } & \text { San Francisco Public Utility Commission } \\ \text { USGS } & \text { U.S. Geological Survey }\end{array}$




\title{
Storage Capacity and Sedimentation Characteristics of the San Antonio Reservoir, California, 2018
}

\author{
By Mathieu D. Marineau, Scott A. Wright, and Joan V. Lopez
}

\section{Abstract}

The San Antonio Reservoir is a large water storage facility in Alameda County, California, and is a major component of the Hetch Hetchy Regional Water System (RWS). The RWS is a water-supply system owned and operated by the San Francisco Public Utilities Commission (SFPUC) and provides water for about 2.7 million people in the San Francisco, Santa Clara, Alameda, and San Mateo Counties. The San Antonio Reservoir is one of two RWS reservoirs in Alameda County and the third largest of the RWS reservoirs in the San Francisco Bay Area. The reservoir was formed by the James H. Turner Dam, which was completed in 1965. At the time of construction, the reservoir was estimated to have 50,500 acre-feet (acre-ft) of storage capacity. That early estimate was based on a 1963 pre-construction topographic map, which was drawn from aerial photographs. The capacity of the reservoir was later surveyed in 1994 and 2000. These two later surveys did not include the upper 18 feet (ft) of the reservoir, which represents roughly 30 percent of the overall storage volume. To determine the storage capacity and provide updated stage-capacity curves up to the spillway, the U.S. Geological Survey, in cooperation with the SFPUC, surveyed the bathymetry and shoreline of the reservoir in April 2018.

The bathymetric survey was performed by making depth soundings using a boat-mounted, multibeam echosounder. At the time of the survey, the water level was between 13 and $14 \mathrm{ft}$ below the spillway elevation. To measure capacity between the water line up to the spillway elevation, topography along most of the shoreline was surveyed from the boat using a terrestrial Light Detection and Ranging (LiDAR) scanner and in other areas by using ground-survey techniques. Location during bathymetric and topographic data collection was determined using a Global Navigation Satellite System-Real Time Network system. Vertical profiles of sound speed were collected periodically. The sound-speed profiles were used to spatially and temporally adjust the sound-speed calculations used to determine depth from the soundings. Approximately 125 kilometers (78 miles) of transects with a total of about 560 million depth soundings and topographic LiDAR points were collected (about 160 per square meter). In addition, approximately 500 topographic survey points were collected in shallow, wadable areas and on land near the upper reservoir area using a Global Navigation Satellite System receiver attached to a fixed length survey rod. Depth soundings, terrestrial LiDAR points, topographic survey points, and a digitized shoreline were merged and interpolated to generate a digital elevation model (DEM) of the reservoir. Gridded elevation data extracted from the DEM were then tabulated to determine total reservoir capacity and create reservoir stage-surface area and stage-storage capacity tables.

Results of the reservoir capacity analysis indicated that the reservoir has 53,266 (plus or minus 140) acre-ft of storage capacity, which is an increase of 2,766 acre-ft (or 5.5 percent) greater than the original 1965 estimate; the increase is likely due to improved survey methods. Also, at the time of this 2018 survey, Intake \#1 (the lowest intake) was not in operation. Intake \#1 is estimated to be buried approximately $10 \mathrm{ft}$ below the bed, whereas Intake \#2 is about $20 \mathrm{ft}$ above the bed. There are five intakes at different elevation levels; however, when consecutive lower intakes become inoperable due to sedimentation, the live storage capacity (capacity available for use) is reduced. At the time of this survey, the remaining live storage (above Intake \#2) was approximately 52,363 acre-ft.

The 2018 stage-capacity curve was compared to the original 1965 stage-capacity curve. Although overall, the changes indicate an increase in storage capacity, the change in volume at $372.7 \mathrm{ft}$ North American Vertical Datum of 1988 (370 ft National Geodetic Vertical Datum of 1929, NGVD 29) shows a decrease of 733 acre-ft (the elevation of $370 \mathrm{ft}$ NGVD 29 was used because it is the lowest elevation available for the 1965 stage-capacity curves). This finding agrees with the observed accumulation of sediment over Intake \#1. That volume was converted to an annual sediment yield of 0.35 acre-ft per square mile (or 165 cubic meters per square kilometer), which is of the same order of magnitude as that found in other watersheds for the Coast Ranges in California. A decrease of 733 acre-ft between 1965 and 2018 thus represents a loss of 1.5 percent of the overall storage capacity in the reservoir. The updated stage-surface area and stage-capacity tables provided in this report and online (https://doi.org/10.5066/P9KC9DU8) can be used by the SFPUC to improve reservoir operations and serve as an accurate baseline to monitor bathymetric changes in the future. 


\section{Introduction}

San Antonio Reservoir, in Alameda County, California, is owned and operated by the San Francisco Public Utilities Commission (SFPUC). The reservoir was formed by the construction of the James H. Turner Dam, which was completed in 1965. The reservoir was surveyed previously in 1994 and 2000 (Sea Surveyor, Inc., 2000). Changes between the 1994 and 2000 surveys indicated a decline in the San Antonio Reservoir storage capacity of about 1.5 percent (Sea Surveyor, Inc., 2000). Those surveys, however, did not include the upper 18 feet (ft) of the reservoir, which includes roughly 30 percent of the total storage volume of the reservoir. The U.S. Geological Survey (USGS), in cooperation with the SFPUC, performed a combined bathymetric and topographic survey, which included areas above the water surface. Those data were analyzed to determine the storage capacity up to the spillway elevation, at the time of this survey, and to create updated stage-surface area and stage-capacity tables.

\section{Purpose and Scope}

The USGS, in cooperation with the SFPUC, conducted a combined bathymetric and topographic survey to determine the storage capacity, at the time of this study, of the San Antonio Reservoir and provide updated reservoir stage-area and stage-capacity curves. Bed-material samples also were collected during this survey to assist in the identification of depositional areas (such as deltas) and to characterize the sediment entering the reservoir. This report presents the methods used to collect survey data, compute reservoir capacity, and collect and analyze bed-material samples. The 2018 reservoir capacity and surface area, which were computed at 0.1 -ft reservoir water-level (stage) increments, are provided in tables in this report. The stage-capacity results from the 2018 survey were compared with those from the 1965 stage-capacity curve (Alexis Dufour, San Francisco Public Utilities Commission, written commun., 2018) to provide an estimate of the quantity of sediment that has been deposited in the reservoir since construction. A detailed interpretation of sedimentation rates and deposition patterns is not included in this report.

The outlet works' intake structure has five intakes at varying elevations, which allow water to be released from the reservoir. However, at the time of this study, bathymetric surveys indicated that sediment deposition over Intake \#1 may be affecting its operation. Inoperable intake structures can reduce the live storage volume. In this report, the volume of storage above each of the five intakes is summarized. In addition, an electronic digital elevation model (DEM) file and comma-delimited files of stage-area and stage-capacity tables are available as a USGS ScienceBase online database at https://doi.org/10.5066/P9KC9DU8 (Marineau and others, 2019).

\section{Description of Study Area}

The San Antonio Reservoir is in Alameda County, California, 34 miles (mi) southeast of San Francisco, at approximately $37^{\circ} 34^{\prime}$ N., $121^{\circ} 50^{\prime}$ W. (fig. 1). At full capacity, the reservoir surface area extends approximately 1.3 square miles $\left(\mathrm{mi}^{2}\right)$ and drains a watershed area of about $38.4 \mathrm{mi}^{2}$. The reservoir was formed after the construction of the James H. Turner Dam in 1965. The earthen dam is $195 \mathrm{ft}$ tall and approximately $2,160 \mathrm{ft}$ in length. The dam crest elevation is approximately $488.7-\mathrm{ft}$ North American Vertical Datum of 1988 (NAVD 88; 486.0-ft National Geodetic Vertical Datum of 1929, NGVD 29), and the spillway elevation was surveyed during this study as 470.9-ft NAVD $88(468.2-\mathrm{ft}$ NGVD 29) ${ }^{1}$. The reservoir is one of two SFPUC reservoirs in Alameda County and serves to store local runoff from the San Antonio watershed and water imported from the Hetch Hetchy Regional Water System. At the time of construction in 1965, the San Antonio Reservoir had an estimated total storage capacity of 50,500 acre-feet (based on stage-capacity tables provided by the SFPUC; Alexis Dufour, San Francisco Public Utilities Commission, written commun., 2018).

Live storage, sometimes called usable storage or watersupply storage, is water storage that is above the lowest-level outlet. The James H. Turner Dam outlet works has five intake structures at varying depths along a 42 -inch (in.) diameter inclined pipe. These structures were referred to as "intakes" in as-built engineering drawings and thus will be referred to as intakes throughout this report. At the time of the 2018 survey, only the upper four structures could be identified from three-dimensional images produced from high-resolution bathymetric survey data.

The climate in Alameda County, California, is classified as a warm summer Mediterranean type based on the Köppen classification system (Idaho State Climate Services, 1999), which is characterized by warm, dry summers and cool, wet winters. Mean daytime temperature in Alameda County is 73 degrees Fahrenheit $\left({ }^{\circ} \mathrm{F}\right)$ and temperature generally ranges from about 42 to $80^{\circ} \mathrm{F}$ (National Oceanic and Atmospheric Administration, 2018b). Average annual precipitation is approximately $19 \mathrm{in}$. and most of this precipitation falls between November and March. The storms producing the greatest amount of precipitation result from extratropical cyclones (Dettinger and others, 2011), which are commonly referred to as "atmospheric rivers."

${ }^{1}$ SFPUC previously reported the elevation of the spillway as $468.31 \mathrm{ft}$ NGVD 29 (471.05 NAVD 88). 


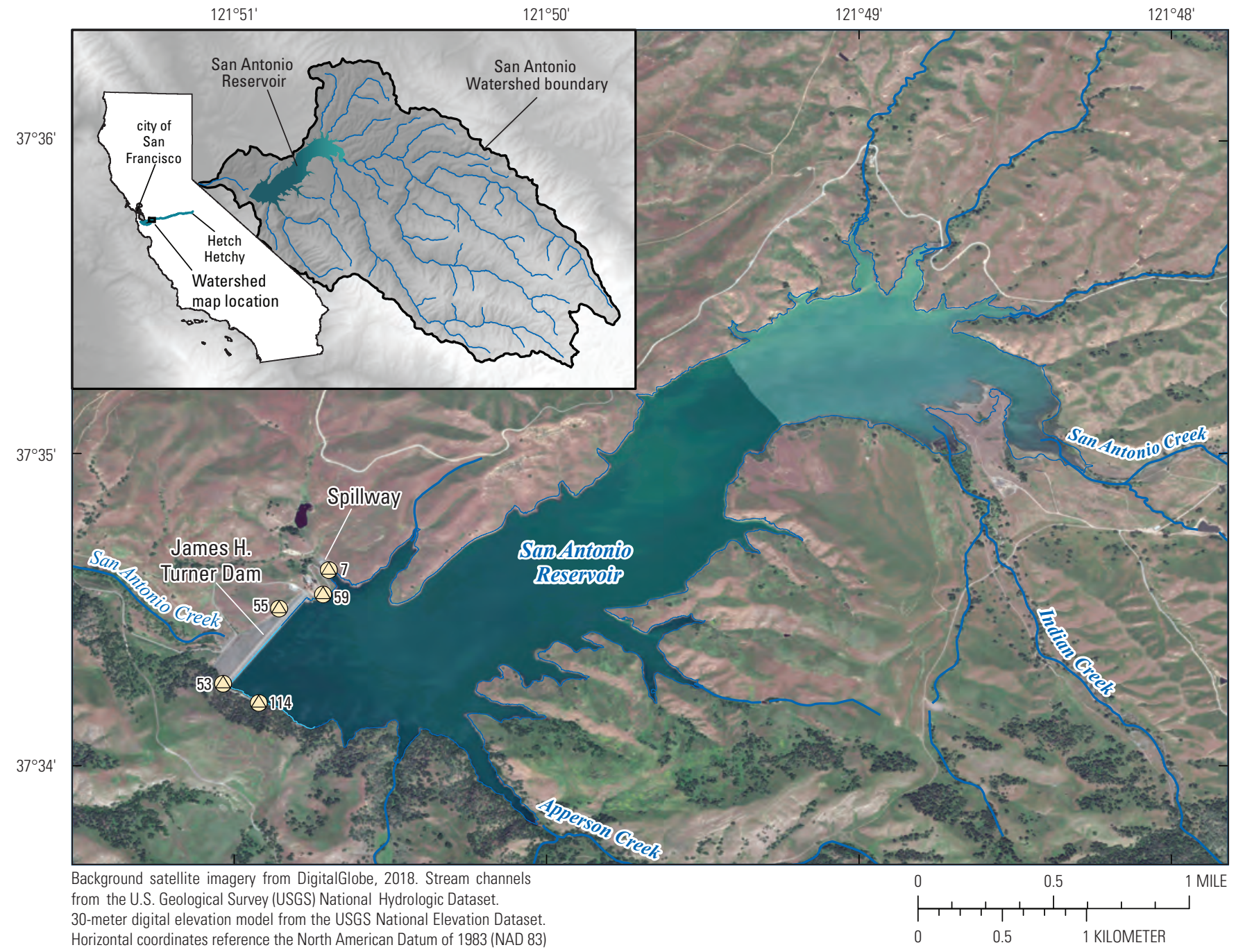

EXPLANATION

Q7 Monumented benchmarks

Figure 1. San Antonio Reservoir and Watershed, California.

The watershed surrounding the reservoir is small relative to the size of the reservoir. Several small tributary creeks are near the east end of the reservoir and small gullies surround much of the reservoir, but most of the watershed is drained by two longer creeks entering the reservoir's eastern end-San Antonio Creek and Indian Creek (fig. 1). The stream channels are dry most of the year. The watershed is generally hilly to the north and east with grasslands and native oak species. To the south, the terrain is much steeper and more heavily vegetated with large shrubs and trees, especially on slopes with northward aspect.

\section{Vertical Datums and Previous Reservoir Surveys}

The official vertical datum in North America, at the time of this report, was NAVD 88; however, the dam construction predates this datum by several decades. Most of the construction documents, survey markers, and stage-surface area/stage-capacity curves are referenced to NGVD 29, which was the official vertical datum before NAVD 88. Conversion of orthometric heights from one datum to the other typically requires addition or subtraction, however, the magnitude of the difference between the two datums depends on geographic location. To calculate the orthometric height conversion, the online VERTCON 2.0 tool was used with a number of benchmarks having known NGVD 29 coordinates (VERTCON 2.0, https://www.ngs.noaa.gov/ cgi-bin/VERTCON/vert_con.prl; Milbert, 1999). Conversion to NAVD 88 requires the addition of $2.74 \mathrm{ft}$ to elevations referenced to NGVD 29. The same conversion (plus $2.74 \mathrm{ft}$ ) was used for all benchmarks referenced in this report. 
The first reservoir capacity estimate was completed in 1963, before construction of the James H. Turner Dam (Bechtel Corporation, 1963a). The 1963 estimate was based on a topographic contour map by R.M. Towell, Inc., which was drawn using photogrammetry from 1959 aerial photographs dated April 8, 1959 (Bechtel Corporation, 1963a). As-built (post construction) surveys were not performed. In the absence of an as-built survey, the 1963 topographic map was used by Bechtel to create estimated stage-surface area and stagecapacity curves (Bechtel Corporation, 1963a). The SFPUC uses a 1 - $\mathrm{ft}$ interval tabulated version of the original stagecapacity curve to support reservoir operations (Alexis Dufour, San Francisco Public Utilities Commission, written commun., October 3, 2018) and in this report it will be referred to as the "1965 stage-capacity curve."

The next surveys, which were bathymetric, were completed in 1994 and 2000 by Sea Surveyor, Inc. (henceforth, Sea Surveyor). The 2000 bathymetric survey was done on August 8,2000, while the lake level was at $461.0 \mathrm{ft}$ NGVD 29 (463.7 ft NAVD 88). Reservoir stagecapacity data were reported only for elevations between 310.5 and $450 \mathrm{ft} \mathrm{NGVD} 29$ (313.2 and $452.7 \mathrm{ft}$ NAVD 88, respectively), and did not provide capacity data for the upper $18 \mathrm{ft}$ of the reservoir between reservoir stage and spillway crest. The 1994 survey also was done while the lake level was at $461.0 \mathrm{ft}$ NGVD 29 (Sea Surveyor, Inc., 2000). However, at the time of the publication of this report, neither the 1994 report nor the detailed 1994 survey data were available. The only information available was that referenced in the 2000 Sea Surveyor report. Based on the 2000 survey, Sea Surveyor concluded that the San Antonio Reservoir was approximately $0.5 \mathrm{ft}$ shallower in 2000 than in 1994; and "the reservoir has approximately 1.5 percent less capacity than in 1994" (Sea Surveyor, Inc., 2000).

The 2000 survey used a boat-mounted, single-beam transducer and Global Positioning System (GPS) for horizontal control (Sea Surveyor, Inc., 2000); however, the accuracy of the control was not reported. If the 2000 survey used low-accuracy methods for horizontal and vertical control, then uncertainty and "noise" in the 2000 survey data could make it difficult to identify small changes in bathymetry during 2000-18, potentially obscuring areas of deposition.

\section{Data and Sample Collection}

The equipment and methods used to collect the topographic and bathymetric data and bed-material samples are described in this section. All fieldwork was completed during April 16-20, 2018. The survey used a Global Navigation Satellite System-Real-Time Network (GNSSRTN) system, which was integrated with the bathymetric and topographic survey equipment to obtain real-time elevation measurements for all points. This eliminated the need to collect and process continuous water-surface elevation data, which are commonly used to convert depth soundings to elevations. Continuous water-surface data were still collected as a backup, as described below. During the time of the survey, the water-surface elevation increased slightly (about $1 \mathrm{ft}$ ) from about 454.0 to $455.0 \mathrm{ft}$ NAVD 88 (approximately 451.3 to $452.3 \mathrm{ft} \mathrm{NGVD} \mathrm{29).} \mathrm{For} \mathrm{reference,} \mathrm{such} \mathrm{reservoir} \mathrm{stages} \mathrm{are}$ $13-14 \mathrm{ft}$ below the spillway crest.

\section{Equipment}

The following is a list of equipment used during the bathymetric survey, shoreline topographic survey, and bedmaterial sampling.

- 19-ft Koffler aluminum boat with outboard jet motor

- Norbit iWBHSh STX Multibeam Sonar System with built-in Inertial Navigation System (INS)

- Norbit integrated Light Detection and Ranging (LiDAR) built using Velodyne VL-16 LiDAR

- Field laptop with Quality Positioning Services B.V. (QPS) Quality Integrated Navigation System (QINSyTM) and QPS Qimera ${ }^{\mathrm{TM}}$ software

- Twin Applanix OceanMaster ${ }^{\mathrm{TM}}$ INS Global Navigation Satellite System (GNSS) receivers mounted with vertical offset above multibeam transducer

- AML Oceanographic Base X2 profiler with an SV-Xchange ${ }^{\mathrm{TM}}$ sound-velocity sensor

- Trimble R10 GNSS receiver used as a rover with a 2-meter ( $\mathrm{m} ; 6.56 \mathrm{ft})$, fixed-length carbon fiber survey rod; a bipod and 25-centimeter $(\mathrm{cm} ; 0.80 \mathrm{ft}$ ) extension rod also were used during benchmark surveys

- Trimble TSC3 handheld controller used to program the GNSS receivers and record data

- US BHM-60 rotary-scoop bed-material sampler, cable suspended from boat 


\section{Horizontal and Vertical Controls}

A GNSS-RTN was used for horizontal and vertical control during this study. An Applanix OceanMaster INS GNSS system with twin offset receiver antennas was mounted above the multibeam transducer and terrestrial LiDAR transceiver during bathymetric and shoreline topographic data collection, respectively. During other topographic data collection and benchmark survey work, a Trimble R10 GNSS receiver was used as a rover. Real-time corrections were accessed from the California Survey and Drafting Supply (CSDS) Coastal Network. All bathymetric and terrestrial LiDAR survey data were post-processed using Trimble $\mathrm{RTX}^{\mathrm{TM}}$ positioning service, which incorporates all nearby Continuously Operated Reference Stations. This section describes the coordinate systems used in this survey and locations of monumented benchmarks on or near the dam, which were surveyed during this study to verify accuracy of our bathymetric and topographic survey.

In addition to using GNSS-RTN for vertical and horizontal control during the bathymetric and topographic surveys, five monumented benchmarks, water-surface elevation, and the reservoir staff gage plate were surveyed using GNSS-RTN to check that the vertical control for the 2018 survey aligned with known benchmarks and the water-level elevation datum already used by the SFPUC. Benchmarks and staff gage datum used by the SFPUC are referenced to NGVD 29. The 2018 data were referenced to the NAVD 88 . The differences between these datums and conversions between datums are explained in the following two sections. Details regarding the monumented benchmark survey also are explained in the "Monumented Benchmarks" section below.

\section{Coordinate Systems}

The vertical coordinate system used in this study is NAVD 88. The horizontal geographic coordinate system used is the North American Datum of 1983 (NAD 83) adjusted by the National Geodetic Survey such that it is referenced to the North American plate; it is abbreviated as NAD 83 (2011). The North American Datum of 1983 (2011) is referenced to the National Spatial Reference System (National Geodetic Survey, 2017). The projected coordinate system used in figures in this report is the NAD 83 (2011) Universal Transverse Mercator (UTM) grid for zone 10 north.

\section{Orthometric Height Conversion}

The NAVD 88 vertical coordinate system supersedes the NGVD 29 vertical coordinate system, which was used in earlier surveys. The staff gage plate for the reservoir (used to monitor water-level elevation) and monumented benchmarks around the reservoir are referenced to NGVD 29 in most of the documentation used by the SFPUC. As mentioned above in the "Vertical Datums and Previous Reservoir Surveys" section, orthometric height conversions between NGVD 29 and NAVD 88 were performed using the National Geodetic Survey VERTCON 2.0 online tool (Milbert, 1999). The reported error in conversion between NGVD 29 and NAVD 88 is plus or minus $2 \mathrm{~cm}(0.07 \mathrm{ft})$. Using the VERTCON 2.0 orthometric height conversion tool the datum shift from NGVD 29 to NAVD 88 varied from plus $2.743 \mathrm{ft}$ to plus $2.736 \mathrm{ft}$ between the left dam abutment $\left(37.571^{\circ} \mathrm{N} ., 121.850^{\circ} \mathrm{W}\right.$.), as viewed looking downstream, to the spillway $\left(37.576^{\circ} \mathrm{N}\right.$., $121.845^{\circ} \mathrm{W}$.). These two values were averaged together (plus $2.74 \mathrm{ft}$ plus or minus $0.07 \mathrm{ft}$ ) and applied to the NGVD 29 elevations of all five of the benchmarks surveyed during this study. Elevation information shown in this report is typically provided with reference to NAVD 88 and NGVD 29.

\section{Monumented Benchmarks}

Five monumented benchmarks on or near the dam were surveyed using a GNSS-RTN system (fig. 1). The GNSS-RTN rover consisted of a Trimble R10 GNSS receiver mounted to a 2-meter, fixed-height survey rod with a survey point. Data were logged on a Trimble TSC3 hand-held controller using Trimble Access Software (Trimble, 2013). Benchmarks were occupied for a minimum of 180 epochs (typically 1-second data-collection intervals for a total duration not less than 3 minutes) following recommendations of Rydlund and Densmore (2012). A $25-\mathrm{cm}(0.80-\mathrm{ft})$ survey rod extension also was added to the $2-\mathrm{m}$ rod, the receiver was reinitialized for antenna-height blunder checks, and the benchmark was resurveyed (also following the recommendations of Rydlund and Densmore, 2012). Each monumented benchmark was therefore occupied at least two times. Survey measurements at each benchmark were checked for quality control and then paired occupations were averaged together (for a particular benchmark). Two of the benchmarks were surveyed on two separate dates (BM 7 and BM 114): once in April and once in December 2018 (table 1). For those two benchmarks, surveyed on different dates, the measurements differed by $0.01 \mathrm{ft}$ for BM 7 and $0.05 \mathrm{ft}$ for BM 114 .

The locations of the five monumented benchmarks are shown in figure 1. Benchmark (BM) 7 is on the spillway crest; BM 53 is on the left dam abutment at the base of cliffs; BM 55 is on a hill in front of the dam; BM 59 is on an access road between the dam and the spillway; and BM 114 is at the top of the stairs of the control house. The elevation as reported by the SFPUC and the elevations measured during this study for these five benchmarks are shown in table 1. Benchmark 53 is near the base of steep cliffs and under power lines, both of which could degrade quality of measurement (Rydlund and Densmore, 2012). 
Table 1. Differences between published elevation and 2018 surveyed elevation for monumented benchmarks used for vertical control checks in the April 2018 bathymetric survey of San Antonio Reservoir, California.

[ft, feet; NAVD 88, North American Vertical Datum of 1988; mm/dd/yyyy, month/day/year; BM, benchmark; \pm , plus or minus; NGVD 29, National Geodetic Vertical Datum of 1929; cm, centimeter]

\begin{tabular}{lccccc}
\hline $\begin{array}{c}\text { Surveyed } \\
\text { location }\end{array}$ & Description & $\begin{array}{c}\text { Reported } \\
\text { elevation, } \\
\text { NAVD 88 } \\
\text { (ft) }\end{array}$ & $\begin{array}{c}\text { Survey date } \\
\text { (mm/dd//yyy) }\end{array}$ & $\begin{array}{c}\text { Surveyed } \\
\text { elevation, } \\
\text { NAVD 88 } \\
\text { (ft) }\end{array}$ & $\begin{array}{c}\text { Difference } \\
\text { (ft, surveyed } \\
\text { minus } \\
\text { reported) }\end{array}$ \\
\hline BM 7 & Spillway crest & 471.05 & $04 / 18 / 2018$ & $470.92 \pm 0.05$ & -0.13 \\
BM 53 & Dam abut- & 489.30 & $12 / 11 / 2018$ & $489.13 \pm 0.11$ & -0.17 \\
BM 55 & ment & & & & -0.12 \\
Dam abut- & 461.394 & $12 / 11 / 2018$ & $461.31 \pm 0.03$ & -0.08 \\
BM 59 & Access road & 489.121 & $12 / 11 / 2018$ & $489.00 \pm 0.03$ & -0.12 \\
BM 114 & Control house & 485.82 & $04 / 18 / 2018$ & $485.77 \pm 0.05$ & -0.05 \\
& & & $12 / 11 / 2018$ & $485.72 \pm 0.06$ & -0.10 \\
Mean of differences & & & & -0.10 \\
\hline
\end{tabular}

${ }^{1}$ Stacie Feng, San Francisco Public Utilities Commission, written commun., March 9, 2018, November 7, 2018, and July 17, 2019.

${ }^{2}$ Converted from NGVD 29 to NAVD 88 by adding $2.74 \mathrm{ft}$. Error in datum shift is approximately plus or minus $2 \mathrm{~cm}(0.07 \mathrm{ft})$ using VERTCON 2.0 orthometric height conversion tool (Milbert, 1999; National Oceanic and Atmospheric Administration, 2018a).

${ }^{3} \mathrm{BM} 53$ is below power lines and at the foot of cliffs, which may cause Global Navigation Satellite System interference and multipath issues and could degrade the quality of the measurement (Rydlund and Densmore, 2012).

The spillway (fig. 2) has a brass benchmark in the center of the crest, which was reported to have an elevation of $468.31 \mathrm{ft}$ NGVD 29 (Stacie Feng, San Francisco Public Utilities Commission, written commun., 2018) or 471.05 plus or minus $0.07 \mathrm{ft}$ NAVD 88 (table 1). The elevation of the spillway crest benchmark (BM 7) was surveyed by USGS staff on April 18, 2018, and December 11, 2018, using a fixedlength survey rod with a Trimble R10 receiver. The survey duration was 180 epochs (standard control survey length) with a Virtual Reference Station connection to the CSDS Real-Time Network. No other points on the spillway crest were surveyed. Each end of the spillway crest has steep vertical walls that could cause multipath issues (ambiguous position) when performing a GNSS survey (Rydlund and Densmore, 2012).

Differences between previously published elevations of monumented benchmarks and survey elevation measurements made during this study are listed in the far-right column of table 1 . The differences between the benchmark elevations reported by the SFPUC and those measured during the survey were relatively consistent. The benchmarks measured between
0.05 and $0.17 \mathrm{ft}$ lower than the documented elevations (mean of $-0.10 \mathrm{ft}$ ). All of the benchmarks were surveyed as lower than what was documented by the SFPUC. At the time of this report, detailed survey reports from previous benchmark surveys were not available. The reason for the differences between the survey measurements made for this study and the previously documented survey measurements could not be determined. Given that the previous measurements are in a superseded datum (NGVD 29), it is unlikely that they were collected with accuracies comparable to GNSS survey methods.

\section{Reservoir Stage}

Reservoir stage (water level) is monitored and recorded hourly by a gage operated by San Francisco County in the reservoir (California Data Exchange Center [CDEC] Station: SAT, http://cdec.water.ca.gov/dynamicapp/staMeta?station $\mathrm{id}=\mathrm{SAT})$. An inclined staff gage plate also is on the steps at the control structure for manual observation of reservoir stage. 


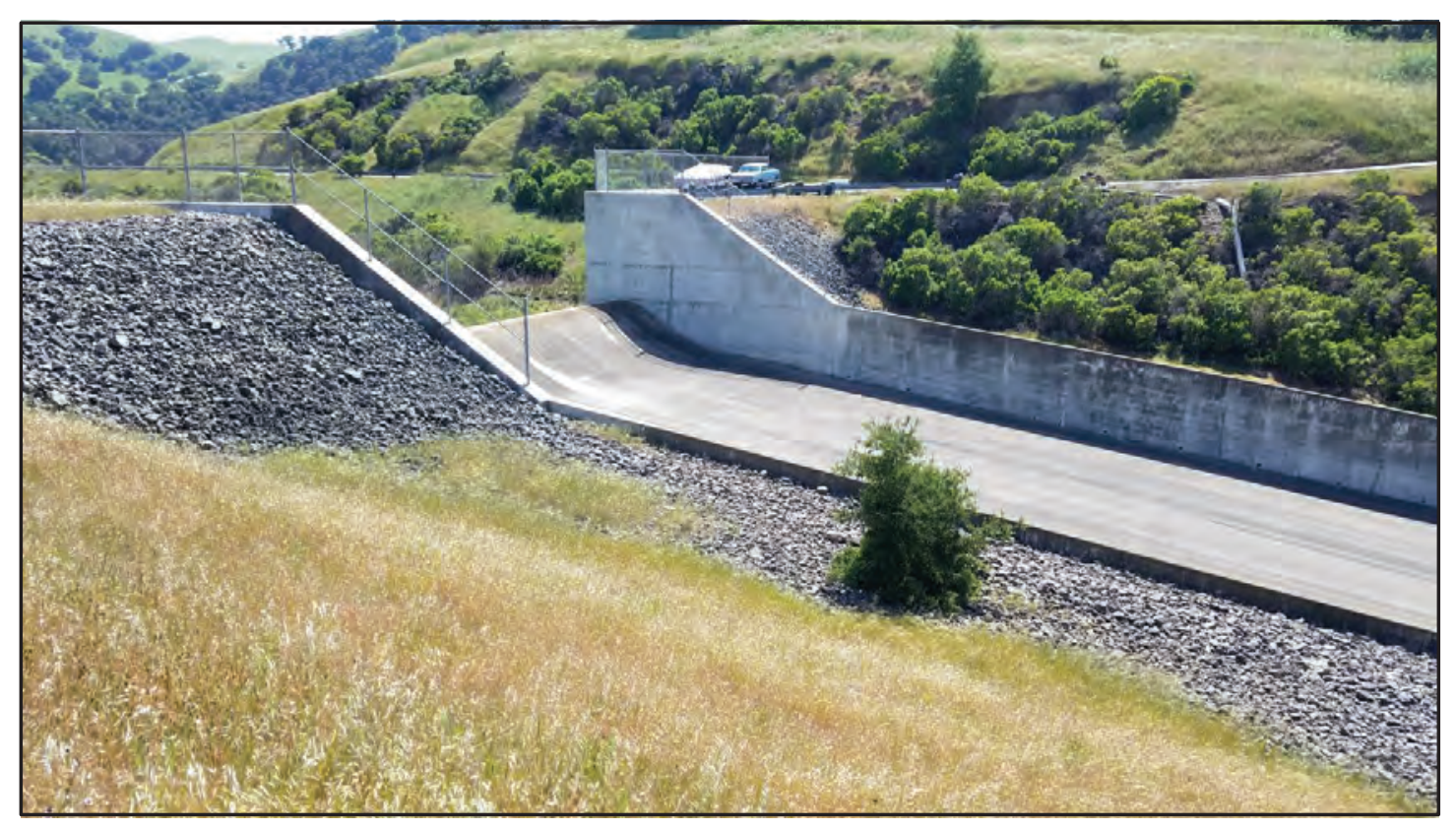

Figure 2. Spillway at the San Antonio Reservoir, California (photograph by Mathieu D. Marineau, U.S. Geological Survey, April 2018).

The stage elevation (gage datum) for the recording gage and staff plate are referenced to the NGVD 29 vertical datum. In general, during the April 2018 bathymetric survey, reservoir storage was approximately 81 percent of full capacity at an average elevation of about $457.4 \mathrm{ft}$ NAVD $88(454.7 \mathrm{ft}$ NGVD 29) or about $13.5 \mathrm{ft}$ below the spillway elevation. The water-surface elevation increased slightly (about $1 \mathrm{ft}$ ) during the survey. Figure 3 shows the water-surface elevation during the time of the survey as recorded by the CDEC station. In addition, water-level data were collected during the survey using an Onset MX2001 ${ }^{\mathrm{TM}}$ logger (referred to herein as "temporary stage logger") at a 1-minute sampling frequency and water-surface elevations were checked two times using GNSS-RTN: the water surface was surveyed once on April 17 and again on April 18, 2018 (fig. 3). The temporary stage logger was installed next to the inclined staff gage plate (the GNSS-RTN water-surface elevation measurements were collected at the same location). Reservoir-stage data from CDEC (Station: SAT) were missing for about two-thirds of the survey. Figure 3 also shows that the existing water-level sensor that CDEC uses may drift from time to time (based on comparison of CDEC data to the temporary stage logger data and the GNSS-RTN surveys of water-surface elevation). The temporary stage logger data were collected as a backup in the event the vertical GNSS position became unavailable; however, the GNSS-surveyed, bathymetric-topographic dataset was complete, so these data were not needed for the analysis portion of this study. 


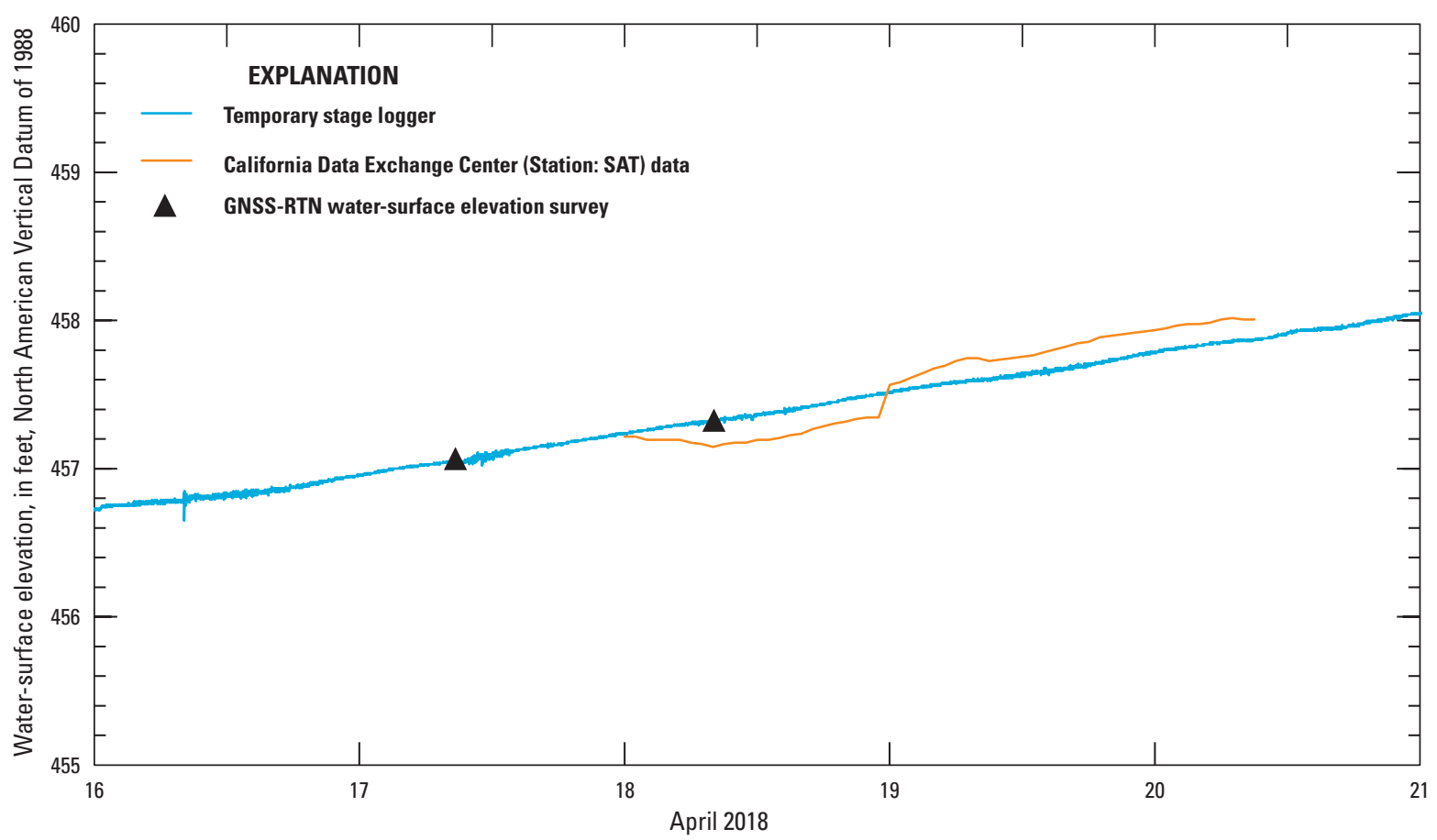

Figure 3. Reservoir stage recorded (reported by California Data Exchange Center gage and temporary U.S. Geological Survey sensor) and water-surface elevation measurements April 16-20, 2018, San Antonio Reservoir, California. Date tick marks are on 0:00 hour of the new day.

\section{Bathymetric and Topographic Survey}

To complete the reservoir survey, three types of survey datasets were collected (1) multibeam bathymetric data, (2) terrestrial-LiDAR topographic data, and (3) ground-based GNSS topographic survey data. The multibeam bathymetric and terrestrial-LiDAR topographic data were collected from a motorized boat while the GNSS topographic survey data were collected by walking or wading in the upper reservoir area that could not be surveyed by boat. Some additional data were collected to support the survey work such as underwater sound-speed profiles (used to correct sound speeds calculated by the multibeam system software) and a topographic benchmark survey.

\section{Bathymetric Data Collection Using Multibeam}

Bathymetric data were collected using a boat-mounted Norbit iWBHSh STX Multibeam Sonar System (multibeam). The multibeam was attached to the side of the 19- $\mathrm{ft}$ aluminum Koffler motorized boat using a carbon fiber mount, such that the reference point on the multibeam was at a depth of $1.15 \mathrm{ft}$ (measured from the water surface).
The multibeam uses 256 beams and has a maximum swath width of 165 degrees (swath width during the survey ranged between 130 and 160 degrees). It operates at a nominal sonar frequency of 400 kilohertz $(\mathrm{kHz})$, and depth data (soundings) were typically recorded at 10 hertz $(\mathrm{Hz})$. Twin external Applanix OceanMaster INS GNSS receivers mounted offset above the multibeam collected position and heading data. A built-in INS measured pitch, roll, and yaw, and those measurements were used to make geometric corrections to depth soundings. In addition, an AML Base X2 underwater sound-velocity profiler was used to collect vertical profiles of underwater sound velocity several times a day and in different parts of the reservoir. These sound-speed profiles were used to make automatic corrections to the multibeam data affected by changes in sound speed caused by water temperature differences (see the "Sound-Speed Profiles" section below for more detailed discussion on this topic). After the instrumentation was mounted on the first day, a multibeam patch test was performed to check the alignment of the sensors. System checks and compass calibration of the multibeam were performed daily. Data were recorded on a field laptop using QINSy and Qimera software (Quality Positioning Services, 2018a, b). 


\section{Motorized Boat Survey Path}

The approach for conducting the bathymetric survey was to separately survey the entire perimeter (shoreline) and interior portions of the reservoir continuously. These two parts of the survey can be performed in any order. The perimeter was surveyed by following the entire shoreline as closely as possible (given the water depth) and logging bathymetric and topographic data using the multibeam and the NORBIT LiDAR, respectively; distance to the shoreline was generally between 10 and $20 \mathrm{ft}$. During the shoreline survey, the aim of the multibeam was configured at an angle toward the shoreline, thus minimizing the gap between sonar- and LiDAR-measured data at the shoreline. The interior of the reservoir was loosely divided into three sections based on overall depth and each section was surveyed by generally following parallel lines (fig. 4). Gaps between the large middle sections of the reservoir and shoreline path were then filled in. At the end of each day, the data were post-processed to determine areas that may need to be resurveyed to improve accuracy. Figure 4 shows an outline of the reservoir and the location of all boat tracks during the bathymetric survey.

\section{Multibeam Calibration}

The transducers in the Norbit multibeam and terrestrial LiDAR were calibrated using a patch test to resolve minor misalignments in the instruments. The patch tests were performed by collecting and processing swaths of overlapping bathymetric and terrestrial topographic data (Norbit, 2018b). A tool in the QINSy software detects errors in depth and elevation between the overlapping portions of the swaths and then makes adjustments to correct those errors (Norbit, 2018b). The INS is calibrated using heading alignment calibration (Norbit, 2018a).

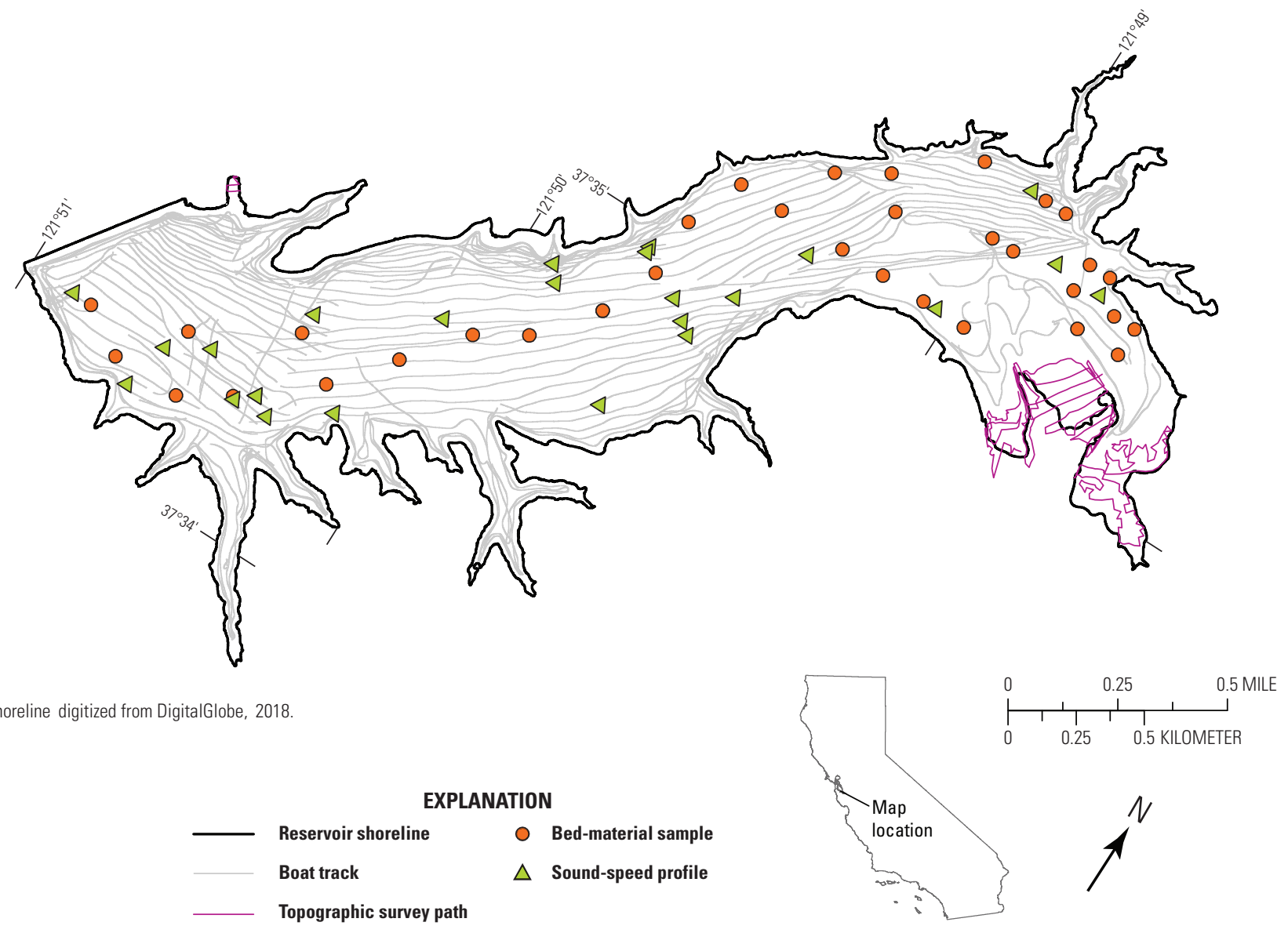

Figure 4. Boat tracks, topographic survey paths at San Antonio Creek delta, and locations of bed-material samples and sound-speed profiles, San Antonio Reservoir, California, 2018. 


\section{Sound-Speed Profiles}

The density of water is primarily affected by the temperature in freshwater reservoirs. Changes in the density above and below a thermocline will affect the speed of sound underwater (referred to as "sound speed"). Sound-speed variation in the water column, if uncorrected, can introduce error in depth measurements collected using acoustically based survey instruments. A $10^{\circ} \mathrm{F}$ decrease in freshwater temperature (for example, from 65 to $55^{\circ} \mathrm{F}$ ) can decrease the sound speed by about 54 feet per second (ft/s), or 1.1 percent (determined from calculations using the Chen and Millero, 1977, equation for sound speed). Failure to account for vertical stratification in water temperature could thus result in an overestimate of sound speed leading to a positively biased (biased high) estimate of depth (resulting in an overestimation of reservoir capacity). Because of this effect, vertical profiles of underwater sound speed were collected periodically during the 2018 survey. These sound-speed profiles were collected using an AML Oceanographic Base X2 profiler with an SV-Xchange ${ }^{\mathrm{TM}}$ sound-velocity sensor (sound-speed profiler). Generally, a sound-speed profile was collected at the start of the survey, during the survey approximately every $1-2$ hours or after moving to a new location, and at the end of the survey (locations of profiles are shown in fig. 4). The soundspeed profiler has an internal GPS receiver for measuring the horizontal location of each sound-speed profile; it can operate in depths up to $328 \mathrm{ft}(100 \mathrm{~m})$ with a sound-speed accuracy of 1 inch per second (in./sec; 0.025 meters per second, $\mathrm{m} / \mathrm{s}$ ). A total of 24 sound-speed profiles were collected during the survey (fig. 4).

\section{Topographic Data Collection Using Terrestrial Light Detection and Ranging and Global Navigation Satellite System Ground- Survey Methods}

Terrestrial LiDAR data were collected using a Norbit LiDAR, which used a Velodyne VL-16 LiDAR unit. The Norbit LiDAR was mounted approximately $5 \mathrm{ft}(1.5 \mathrm{~m})$ above the multibeam on the same carbon fiber pole and faced outwards to the starboard side of the watercraft. Positional data were collected in the same manner as that described above for the multibeam; moreover, topographic position corrections for roll, pitch, and yaw also were applied using identical methods as used for bathymetric data.

A large portion of the upper part of the reservoir was above water level, but below spillway crest elevation (the reservoir was not completely full at the time of the survey). The terrestrial LiDAR could not adequately reach much of that area from the boat due to the maximum range of the LiDAR system, and large lidar shadow zones (no data) caused by the combination of low view angle, rugged terrain, and dense vegetation. In this area, the R10 GNSS rover was used with a $6.56 \mathrm{ft}(2.00 \mathrm{~m})$ survey rod to collect enough topographic points to capture the general terrain in this area. The measurements were surveyed using a Trimble R10 receiver, which was connected to the CSDS coastal Real-Time Network (RTN) to receive GNSS-RTN corrections. The locations of GNSS-RTN ground-survey measurements are shown as "topographic survey path" in figure 4.

\section{Real-Time Multibeam, Sound Speed, and Terrestrial Light Detection and Ranging Integration}

All multibeam and terrestrial LiDAR data were collected while using a GNSS-RTN system and INS that integrated position, roll, pitch, and yaw to obtain real-time $\mathrm{X}, \mathrm{Y}$, and $\mathrm{Z}$ coordinates of all survey points on the reservoir bed and exposed shore. This type of data-collection platform eliminated the need for collecting water-level data during the survey and compensating for changes in water-surface elevation. As discussed previously in the "Reservoir Stage" section, water-level data were collected as a backup (fig. 3); however, since vertical GNSS position data were collected during the entire survey, these additional water-level data were not used for analysis.

\section{Bed-Material Sampling}

Bed material was sampled using a US BMH-60, which is a rotary-scoop bed-material sampler, following standard USGS protocols for use of these samplers (Edwards and Glysson, 1999; Davis, 2005) from a motorized boat. Rotaryscoop samplers are designed to collect material from the top $5 \mathrm{~cm}$ of the bed. Samples were generally collected along the centerline of the reservoir where the old creek channel was and near the upper end of the reservoir where several tributaries flow into the reservoir. Approximate locations of bed-material samples are shown in figure 4 .

The locations of sample collection were recorded using the boat's on-board GPS navigation system. The accuracy of the boat's on-board GPS was about plus or minus $8 \mathrm{ft}(2.5 \mathrm{~m}$; Johnson Outdoors Marine Electronics Inc., 2014). The GPS receiver for the boat is on the stern, whereas the sampler is suspended off the bow. Additional information about sampling (date, time, and depth of sample) also was recorded and is available in the "Bed-Material Composition" section later this report. 


\section{Data Analysis}

Raw depth-sounding data were first corrected for changes in sound speed, resulting from potential thermoclines. The sound speed corrected depth data were then converted to bathymetric elevations and merged with topographic datasets and the shoreline data. The merged point data were interpolated to obtain a $3.3-\mathrm{ft}(1-\mathrm{m})$ resolution raster DEM of the survey. This DEM was used to compute reservoir storage capacity.

\section{Shallow-Water Survey, Spillway Elevation, and Shoreline Digitization}

The GNSS-RTN ground-survey measurements were processed in Trimble Business Center software (Trimble, 2014). The GNSS-RTN ground-survey measurements were then combined with the bathymetric dataset.

The two survey measurements of BM 7 (April 30, 2018, and December 11, 2018), which is the spillway crest benchmark, differed by $0.01 \mathrm{ft}$; resulting in an average elevation for BM 7 of 470.93 plus or minus $0.05 \mathrm{ft}$ NAVD 88 (468.19 ft NGVD 29). The spillway crest elevation was rounded down to $470.9 \mathrm{ft}$ NAVD 88 when calculating the reservoir storage volume.

Several small areas of the shoreline could not be reached by terrestrial LiDAR or accessed easily with GNSS-RTN ground survey. These were typically small gullies that were inaccessible using the motorized boat; generally, these areas were small and the water was shallow (less than $2 \mathrm{ft} ; 0.6 \mathrm{~m}$ ). To quantify these areas, a contour representing the spillway elevation was used to aid in the interpolation between measured bathymetric and topographic points. This contour, which represents the shoreline when the reservoir is full, was drawn from high-resolution $(1.6 \mathrm{ft} ; 0.5 \mathrm{~m})$ WorldView 2 Satellite imagery of the reservoir (fig. 1), dated March 16, 2016 (Digital Globe Inc., 2018). The imagery was collected when the reservoir was at full capacity (468.48 ft NGVD 29; $471.22 \mathrm{ft} \mathrm{NAVD} \mathrm{88),} \mathrm{which} \mathrm{was} \mathrm{based} \mathrm{on} \mathrm{water-level} \mathrm{gage}$ data recorded at the time (CDEC Station: SAT). The shoreline contour line was then converted to discrete points at 1-m (3.3-ft) intervals using ArcGISTM (Environmental Systems Research Institute [ESRI] Inc., 2017), and assigned an elevation of $471.1 \mathrm{ft}$ NAVD 88 (the elevation was adjusted by $0.1 \mathrm{ft}$ based on differences between reoccupation of benchmarks surveyed in new and previous benchmark surveys). The shoreline point data were then merged with the bathymetric and topographic data.

\section{Sound-Speed Corrections}

The QPS Qimera software integrates multiple measurements made using the sound-speed profiler with the bathymetric data (Quality Positioning Services, 2018a, b). Underwater sound speed was measured directly at different depths using the sound-speed profiler. These underwater sound velocity data were then used to make corrections to the multibeam depth soundings. During the survey, 24 soundspeed profiles were collected; their locations are shown on figure 4. Sound speeds near the surface ranged from about $4,815-4,825 \mathrm{ft} / \mathrm{s}$ and decreased rapidly to about $4,765 \mathrm{ft} / \mathrm{s}$ at a depth of about $40 \mathrm{ft}$. Between 40 and $50 \mathrm{ft}$, the sound speed gradually decreases to about $4,770 \mathrm{ft} / \mathrm{s}(1,454 \mathrm{~m} / \mathrm{s})$. Several examples of these sound-speed profiles are shown in figure 5 .

\section{Digital Elevation Model Development}

The multibeam bathymetric, terrestrial LiDAR, GNSSRTN ground survey, and digitized shoreline points were merged and imported into ArcGISTM (Environmental Systems Research Institute Inc., 2017) as a point shapefile. A DEM was created in ArcGIS by using a nearest neighbor interpolation algorithm with $3.28 \mathrm{ft}(1-\mathrm{m})$ cell size. The elevation data from the DEM were then exported and tabulated in MATLAB ${ }^{\circledR}$ (MathWorks, Inc., 2018) to obtain the surface area and cumulative storage volume at $0.1-\mathrm{ft}$ stage intervals. The bathymetric raster dataset also was used to generate contours at 10-foot intervals using an algorithm in ArcGIS; contour lines shorter than $150 \mathrm{ft}$ were excluded. The remaining contours were smoothed using a PAEK smoothing algorithm (Environmental Systems Research Institute, Inc., 2017).

\section{Multibeam Indirect Depth Check}

As an indirect check that the multibeam had functioned properly, the maximum depth sounded by the bed-material sampler or the sound-speed profiler in several sound-speed profiles was compared to the bed elevation derived from the DEM at the same locations (fig. 6). This indirect depth check was not performed in the field, but was completed after the bathymetric data points were processed and a DEM was generated. 


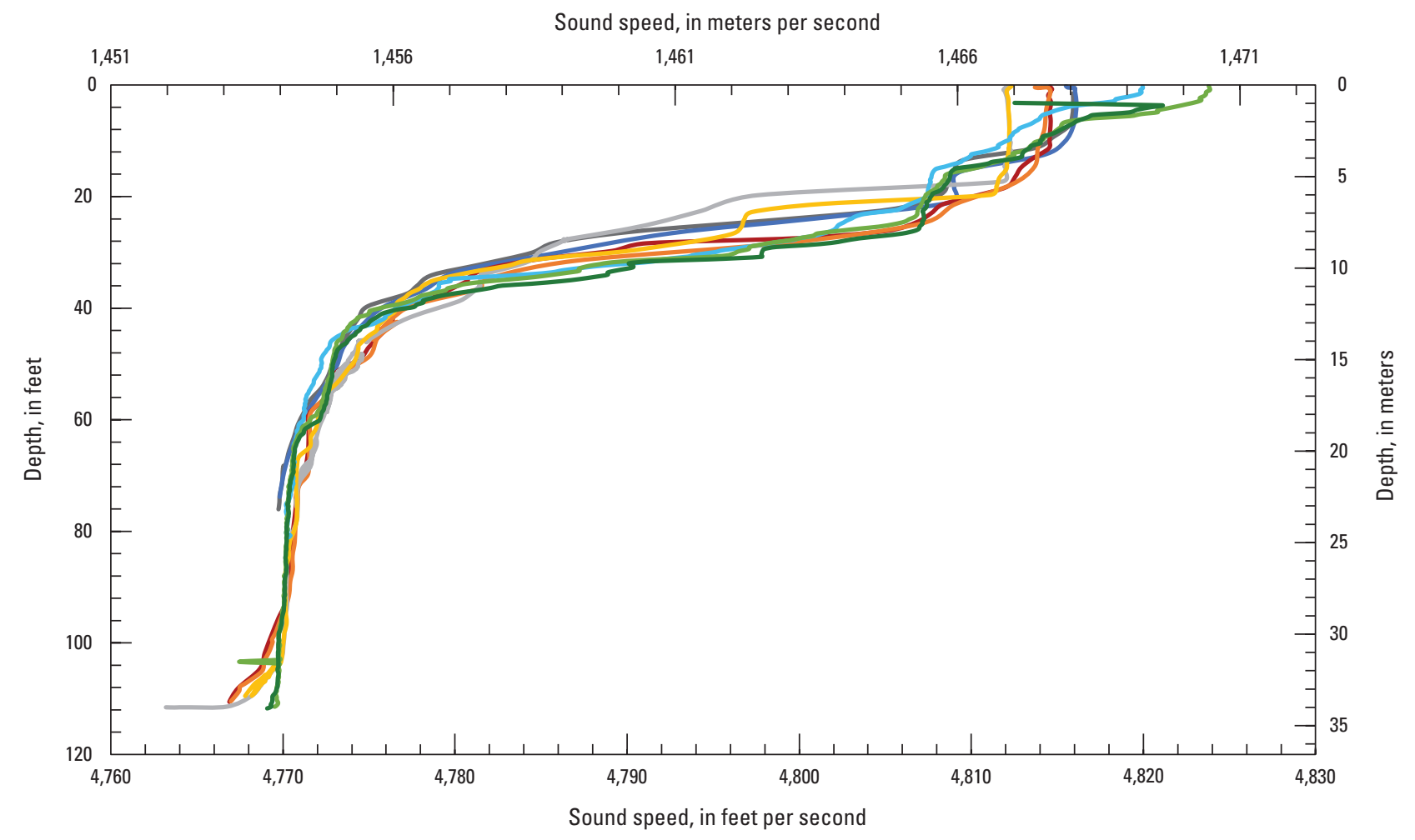

Figure 5. Examples of 10 sound-speed profiles collected during the April 16-20, 2018, survey of San Antonio Reservoir, California. Each color represents a different sound-speed profile; selected profiles are shown here simply for illustrative purposes.

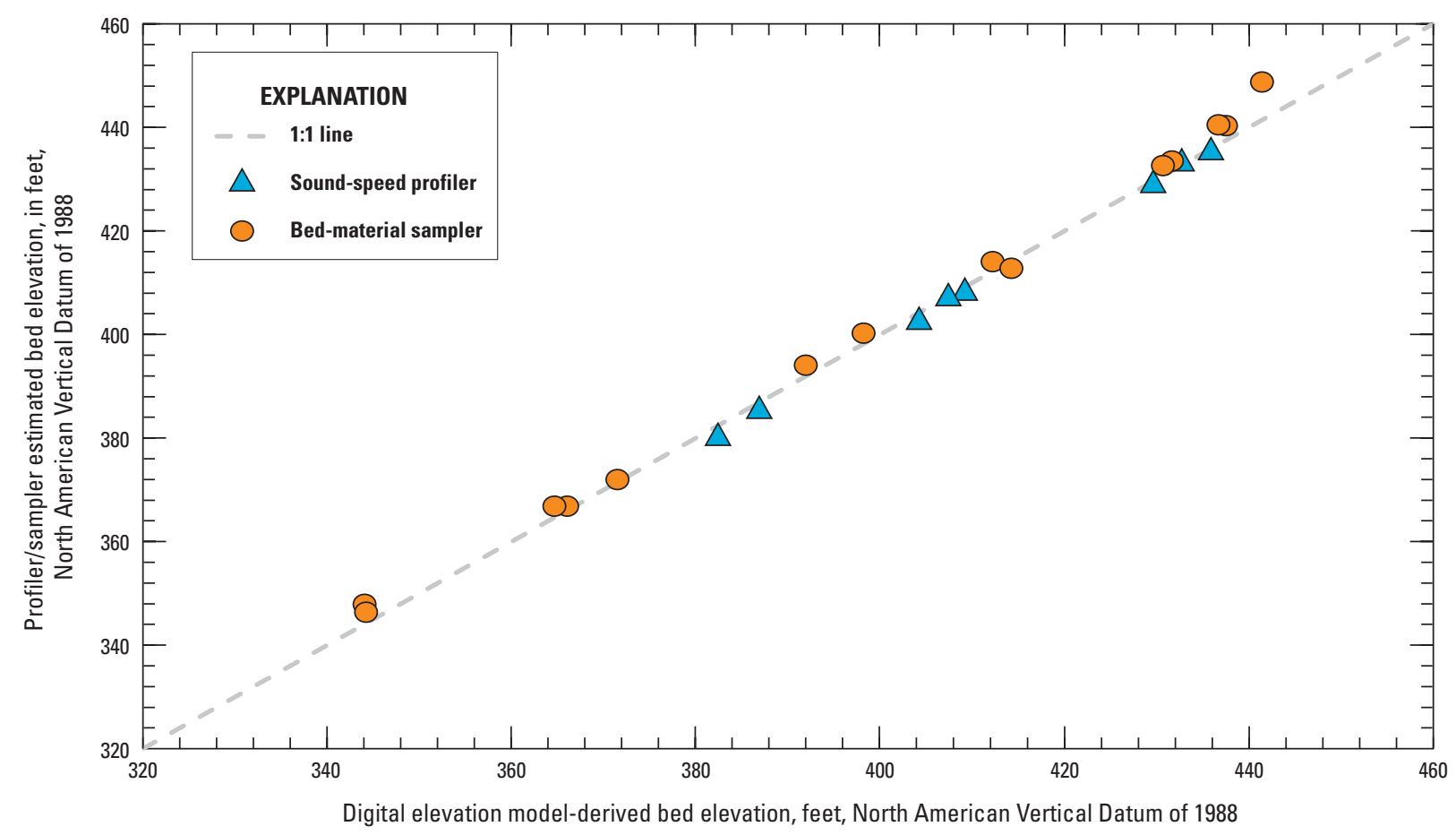

Figure 6. Bed elevation derived from depths measured using the sound-speed profiler and bed-material sampler in relation to bed elevation derived from the digital elevation model (DEM) of the San Antonio Reservoir, California, 2018. Plotted points comprise a subset of the sound-speed profiles and bed-material sampler soundings collected in areas with generally flat lakebed terrain, to provide a more robust check of the DEM-derived bed elevations than points from steeply sloping areas. 
To complete the depth check, sound-speed profiles were culled such that profiles in areas with steep bed topography were not used in the indirect depth-check analysis. The maximum depth recorded by the sound-speed profiler is referred to here as the "profiler-derived depth." The depths measured by the multibeam were the primary bathymetric data used in constructing the DEM; nevertheless, the checked dataset is referred to as the "DEM-derived depth". In those areas where bed topography is steep, if the boat drifted a few feet from the GPS-derived location of the profiler while the profiler was still descending underwater, the profiler-derived depth could differ substantially from the DEM-derived depth. Excluding the profiles collected in areas with mildly sloped to steep bed topography, the average depth of the remaining eight profiles was about $43 \mathrm{ft}(13 \mathrm{~m})$ with a range of $19-75 \mathrm{ft}$ $(5.8-23 \mathrm{~m})$. On average, the profiler-derived depth was $0.30 \mathrm{ft}$ $(0.09 \mathrm{~m})$ shallower than the DEM-derived depth. Differences in depth could be caused by boat drift or vertical offset of the pressure sensor on the sound-speed profiler relative to the base of the instrument. In general, the DEM-derived bed elevations (which are based on multibeam measurements) and soundspeed profiler and bed-material sampler derived elevations corresponded well (fig. 6). In addition to performing daily system checks on the multibeam, this indirect check against the profiler- and sampler-measured depths provided assurance that the Norbit multibeam was functioning properly and measuring elevations accurately.

\section{Bed-Material Sample Preparation and Particle- Size Analysis}

Bed-material samples were dried in an oven at 105 degrees Celsius $\left({ }^{\circ} \mathrm{C}\right)$. After samples were dried, clumps of sediment were disaggregated using a mortar and pestle. Particle-size distribution of the sample material was then determined using a combination of laser diffraction measurement and sieving.

Sieving of sediment particles with size greater than 1 millimeter $(\mathrm{mm})$ followed standard sieving methods (Edwards and Glysson, 1999). The total weight of each size class was recorded and then used with the sieve data to determine the particle-size distribution.

The median $\left(\mathrm{D}_{50}\right)$ and 90th-percentile $\left(\mathrm{D}_{90}\right)$ grain sizes were calculated using linear interpolation between logarithmically transformed particle-size classes. The percentages of fine sediment, sand, and gravel in each sample also were calculated. Clay sediment is smaller than $0.004 \mathrm{~mm}$; silt is from 0.004 to less than $0.063 \mathrm{~mm}$; sand is from 0.063 to less than $2 \mathrm{~mm}$; and gravel is from 2 to less than $64 \mathrm{~mm}$.

\section{Particle-Size Distribution Using a Laser Diffraction Particle-Size Analyzer}

Subsamples of bed material for all sample sets were processed using the LS 13-320 Laser Diffraction Particle-Size Analyzer (analyzer). This instrument is limited to particles with a nominal diameter less than $2 \mathrm{~mm}$ (Beckman Coulter, Inc., 2009). Coarser angular particles between 1 and $2 \mathrm{~mm}$ can be problematic and clog the instrument. Therefore, the coarser material (with a nominal diameter greater than $1 \mathrm{~mm}$ ) was sieved during sample preparation and weighed separately using sieves ranging from 1 to $11 \mathrm{~mm}$ (no samples contained particles larger than $11 \mathrm{~mm}$ ). The analyzer measures the percent by volume of particles for 96 size classes ranging from 0.000375 to $2 \mathrm{~mm}$. The $\mathrm{D}_{50}$ and $\mathrm{D}_{90}$ were calculated using linear interpolation between the nearest size classes. The analyzer used the Fraunhofer model to estimate particle size based on the measurements of light diffraction (Beckman Coulter, Inc., 2009). Data for size classes finer than 0.004, $0.008,0.016,0.0313,0.0625,0.125,0.25,0.5$, and $1 \mathrm{~mm}$ (corresponding to 1 phi increments) were interpolated between the nearest size classes recorded by the analyzer. For samples containing particles larger than $1 \mathrm{~mm}$, the percent by mass of particles larger than $1 \mathrm{~mm}$ was used to recalculate the particlesize distribution, and $\mathrm{D}_{50}$ and $\mathrm{D}_{90}$. Details on this procedure are described in the next section.

\section{Samples Containing Coarse Material}

Samples containing coarse material (greater than $1 \mathrm{~mm}$ ) required separate measurements because the analyzer is limited to measuring particles up to $1 \mathrm{~mm}$ in size. Particles between 1 and $11 \mathrm{~mm}$ were dry sieved in a Ro-Tap ${ }^{\circledR}$ sieve shaker using the standard sieving method (Edwards and Glysson, 1999). The analyzer-measured particle-size distribution along with sieved $(1-11 \mathrm{~mm})$ distribution, were combined to recalculate the full-range particle-size distribution. The particle-size distribution output from the analyzer is in the form of volumetric percentage of each size class. To obtain the gravimetric distribution, the volumetric particle-size distribution was multiplied by the mass of the sample fraction that was finer than $1 \mathrm{~mm}$. The calculated values of mass by size class for the particles finer than $1 \mathrm{~mm}$ were combined with all measurements of mass by sieved classes ( $1 \mathrm{~mm}$ and coarser) to calculate the full-range of particle-size distribution. 


\section{Results}

In this section the results of the 2018 San Antonio Reservoir capacity analysis are compared to the initial capacity. The 1965 stage-capacity table was provided by the SFPUC and was based on the pre-construction photogrammetric surveys of the topography (Alexis Dufour, San Francisco Public Utilities Commission, written commun., October 3, 2018). A bathymetric map and bed-material composition results are presented in this section. In addition, an electronic DEM file and comma-delimited files of stagearea and stage-capacity tables are available as a USGS ScienceBase online database at https://doi.org/10.5066/ P9KC9DU8 (Marineau and others, 2019).

\section{Bathymetry}

Results of the 2018 bathymetric survey of the reservoir are shown as a map in figure 7. Approximately 560 million multibeam depth soundings and terrestrial LiDAR points (about 160 per $\mathrm{m}^{2}$, on average), and about 500 GNSS-RTN topographic-survey points were used to create a gridded bathymetric DEM.

The bathymetric DEM shows that remnants of borrow pits from the dam construction are still well defined in the lower reservoir (fig. 7). Although not apparent from the DEM or contour map, evidence exists of minor sedimentation in the lower (deeper) part of the reservoir. The lowest level intake (Intake \#1) appears to be about $10 \mathrm{ft}$ below the bed elevation in that area. Intake \#2 (second lowest intake) is still about $20 \mathrm{ft}$ above the bed in that part of the reservoir and is operational (fig. 8).

\section{Reservoir Storage Capacity}

The total storage capacity of the San Antonio Reservoir (below the spillway crest) determined from the 2018 bathymetric survey was 53,266 acre-ft. Rating tables for the surface area and reservoir volume at $0.1-\mathrm{ft}$ stage intervals are provided in tables 2 and 3. Figure 9 shows the 1965 and 2018 stage-capacity curves. 


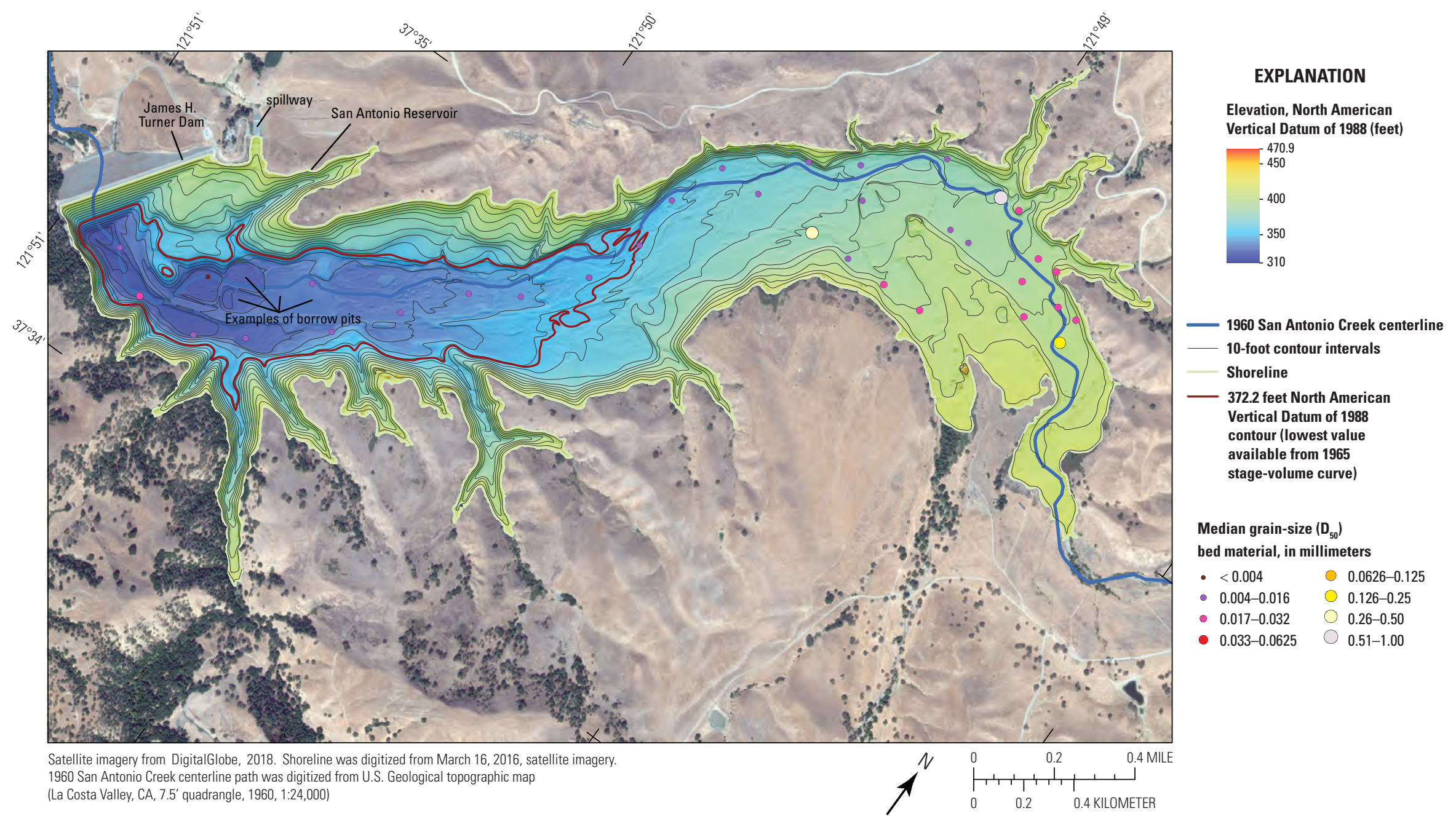

Figure 7. Bathymetry and topography (10-foot contour interval), based on the April 2018 survey, and median grain size $\left(D_{50}\right)$ of bed material at sampled points, San Antonio Reservoir, California. 

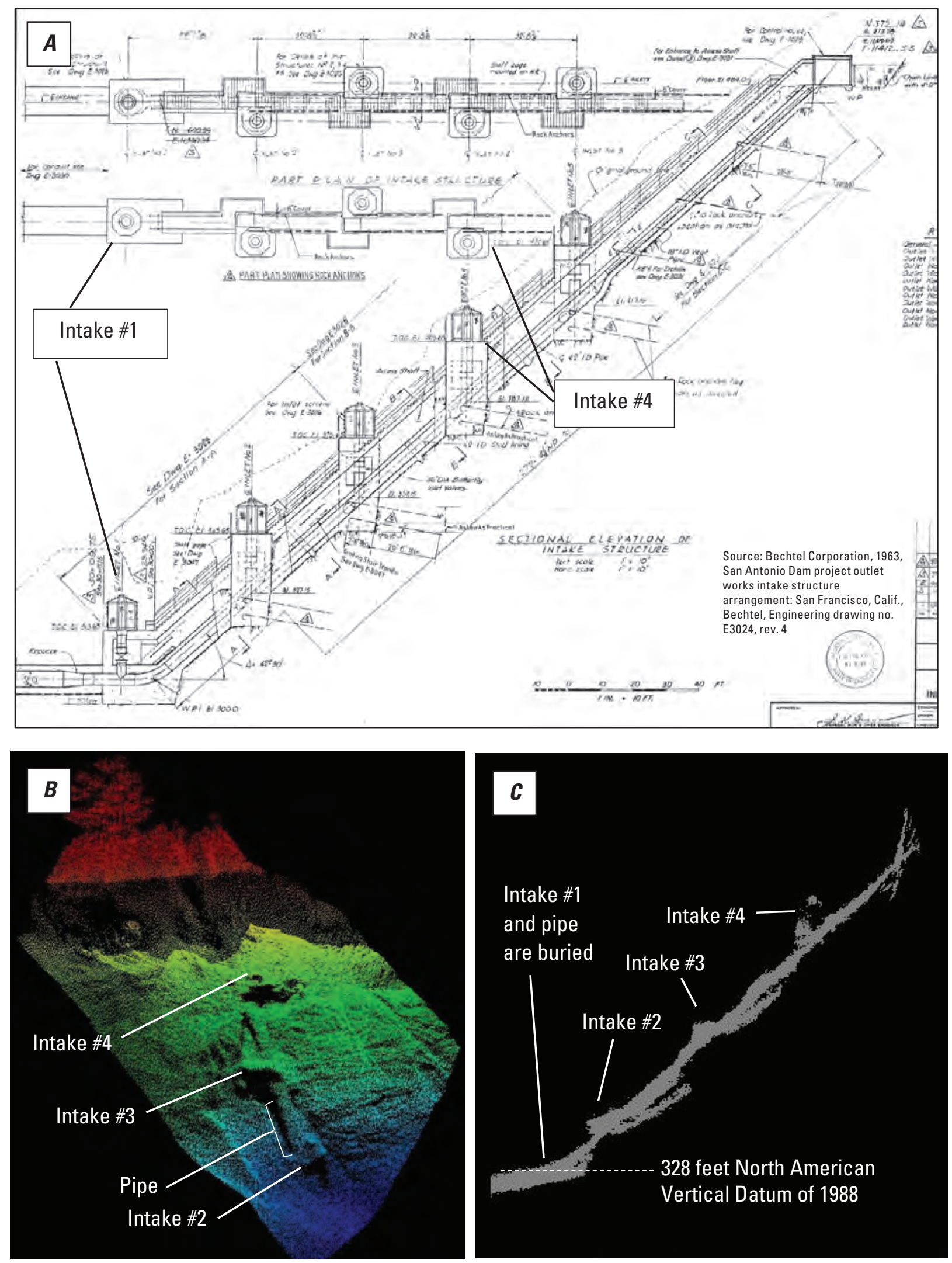

Figure 8. $A$, Cross-sectional profile of intake pipelines, $B$, three-dimensional oblique view of sonar point-cloud image of intake structure, and $C$, cross-sectional profile cut from sonar point-cloud data showing approximate locations of intakes and bed elevation over Intake \#1, San Antonio Reservoir, California, 2018. Images were generated from multibeam sonar point-cloud data. 
Table 2. Rating table for surface area of the San Antonio Reservoir, California, 2018.

\begin{tabular}{|c|c|c|c|c|c|c|c|c|c|c|}
\hline \multirow{2}{*}{$\begin{array}{c}\text { Reservoir } \\
\text { stage } \\
\text { (feet) }^{1}\end{array}$} & \multicolumn{10}{|c|}{$\begin{array}{c}\text { Surface area intervals } \\
\text { (acres) }\end{array}$} \\
\hline & 0 & 0.1 & 0.2 & 0.3 & 0.4 & 0.5 & 0.6 & 0.7 & 0.8 & 0.9 \\
\hline 312 & 0 & 0 & 0 & 0 & 0 & 0 & 0 & 0.1 & 0.1 & 0.1 \\
\hline 313 & 0.1 & 0.1 & 0.2 & 0.2 & 0.2 & 0.2 & 0.2 & 0.3 & 0.3 & 0.3 \\
\hline 314 & 0.3 & 0.3 & 0.3 & 0.3 & 0.3 & 0.3 & 0.3 & 0.3 & 0.4 & 0.4 \\
\hline 315 & 0.4 & 0.4 & 0.4 & 0.4 & 0.4 & 0.4 & 0.4 & 0.4 & 0.5 & 0.5 \\
\hline 316 & 0.6 & 0.6 & 0.7 & 0.7 & 0.8 & 0.8 & 0.9 & 1.0 & 1.0 & 1.1 \\
\hline 317 & 1.1 & 1.2 & 1.2 & 1.3 & 1.3 & 1.3 & 1.4 & 1.4 & 1.5 & 1.5 \\
\hline 318 & 1.6 & 1.7 & 1.7 & 1.8 & 1.8 & 1.9 & 2.0 & 2.0 & 2.1 & 2.2 \\
\hline 319 & 2.2 & 2.3 & 2.3 & 2.4 & 2.4 & 2.5 & 2.5 & 2.6 & 2.6 & 2.7 \\
\hline 320 & 2.7 & 2.8 & 2.8 & 2.9 & 2.9 & 3.0 & 3.0 & 3.1 & 3.1 & 3.1 \\
\hline 321 & 3.2 & 3.2 & 3.2 & 3.3 & 3.3 & 3.4 & 3.5 & 3.5 & 3.6 & 3.7 \\
\hline 322 & 3.8 & 3.8 & 3.9 & 4.0 & 4.0 & 4.1 & 4.2 & 4.2 & 4.3 & 4.4 \\
\hline 323 & 4.5 & 4.6 & 4.8 & 5.0 & 5.2 & 5.4 & 5.7 & 5.9 & 6.2 & 6.4 \\
\hline 324 & 6.6 & 6.8 & 6.9 & 7.1 & 7.3 & 7.5 & 7.7 & 8.0 & 8.2 & 8.5 \\
\hline 325 & 8.7 & 9.0 & 9.3 & 9.6 & 9.9 & 10.2 & 10.5 & 10.7 & 11.0 & 11.2 \\
\hline 326 & 11.4 & 11.6 & 11.8 & 12.0 & 12.2 & 12.3 & 12.5 & 12.7 & 12.8 & 13.0 \\
\hline 327 & 13.1 & 13.3 & 13.4 & 13.5 & 13.7 & 13.8 & 14.0 & 14.1 & 14.2 & 14.3 \\
\hline 328 & 14.5 & 14.6 & 14.7 & 14.8 & 14.9 & 15.1 & 15.2 & 15.4 & 15.6 & 15.8 \\
\hline 329 & 16.0 & 16.2 & 16.3 & 16.5 & 16.6 & 16.7 & 16.9 & 17.0 & 17.1 & 17.3 \\
\hline 330 & 17.4 & 17.6 & 17.8 & 18.0 & 18.2 & 18.4 & 18.5 & 18.8 & 19.0 & 19.3 \\
\hline 331 & 19.6 & 19.9 & 20.2 & 20.5 & 20.7 & 20.9 & 21.1 & 21.3 & 21.5 & 21.7 \\
\hline 332 & 21.8 & 22.0 & 22.2 & 22.4 & 22.5 & 22.7 & 22.8 & 23.0 & 23.1 & 23.3 \\
\hline 333 & 23.5 & 23.8 & 24.0 & 24.3 & 24.5 & 24.7 & 24.9 & 25.0 & 25.2 & 25.4 \\
\hline 334 & 25.6 & 25.8 & 26.0 & 26.2 & 26.4 & 26.5 & 26.7 & 26.9 & 27.1 & 27.2 \\
\hline 335 & 27.4 & 27.6 & 27.8 & 28.0 & 28.2 & 28.4 & 28.6 & 28.8 & 29.1 & 29.3 \\
\hline 336 & 29.5 & 29.8 & 30.0 & 30.2 & 30.4 & 30.6 & 30.8 & 31.0 & 31.2 & 31.4 \\
\hline 337 & 31.6 & 31.8 & 32.1 & 32.3 & 32.5 & 32.7 & 33.0 & 33.2 & 33.5 & 33.7 \\
\hline 338 & 34.0 & 34.2 & 34.5 & 34.8 & 35.0 & 35.3 & 35.6 & 35.9 & 36.2 & 36.4 \\
\hline 339 & 36.7 & 37.0 & 37.2 & 37.4 & 37.7 & 37.9 & 38.2 & 38.4 & 38.7 & 38.9 \\
\hline 340 & 39.2 & 39.4 & 39.7 & 39.9 & 40.2 & 40.4 & 40.7 & 40.9 & 41.2 & 41.4 \\
\hline 341 & 41.7 & 41.9 & 42.2 & 42.4 & 42.7 & 43.1 & 43.4 & 43.8 & 44.2 & 44.8 \\
\hline 342 & 45.6 & 46.3 & 47.1 & 47.8 & 48.4 & 49.2 & 50.0 & 50.8 & 51.7 & 52.4 \\
\hline 343 & 53.2 & 54.0 & 54.9 & 55.8 & 56.7 & 57.6 & 58.4 & 59.3 & 60.1 & 61.0 \\
\hline 344 & 61.7 & 62.4 & 63.1 & 63.8 & 64.4 & 65.0 & 65.6 & 66.3 & 67.0 & 67.7 \\
\hline 345 & 68.3 & 68.9 & 69.6 & 70.2 & 70.9 & 71.6 & 72.2 & 72.7 & 73.3 & 73.9 \\
\hline 346 & 74.5 & 75.0 & 75.6 & 76.2 & 76.7 & 77.3 & 77.8 & 78.4 & 79.0 & 79.5 \\
\hline 347 & 80.0 & 80.5 & 81.0 & 81.5 & 82.0 & 82.5 & 83.0 & 83.4 & 83.9 & 84.3 \\
\hline 348 & 84.8 & 85.3 & 85.8 & 86.3 & 86.9 & 87.5 & 88.1 & 88.7 & 89.2 & 89.7 \\
\hline 349 & 90.3 & 90.8 & 91.3 & 91.7 & 92.2 & 92.7 & 93.2 & 93.7 & 94.3 & 94.8 \\
\hline 350 & 95.4 & 95.9 & 96.4 & 96.8 & 97.3 & 97.8 & 98.2 & 98.6 & 99.0 & 99.5 \\
\hline 351 & 99.9 & 100.3 & 100.8 & 101.2 & 101.6 & 102.0 & 102.4 & 102.7 & 103.0 & 103.4 \\
\hline 352 & 103.7 & 104.1 & 104.5 & 104.9 & 105.3 & 105.7 & 106.1 & 106.5 & 106.9 & 107.2 \\
\hline 353 & 107.6 & 107.9 & 108.3 & 108.6 & 109.0 & 109.3 & 109.7 & 110.1 & 110.5 & 110.8 \\
\hline
\end{tabular}


Table 2. Rating table for surface area of the San Antonio Reservoir, California, 2018.-Continued

\begin{tabular}{|c|c|c|c|c|c|c|c|c|c|c|}
\hline \multirow{2}{*}{$\begin{array}{c}\text { Reservoir } \\
\text { stage } \\
\text { (feet) }^{1}\end{array}$} & \multicolumn{10}{|c|}{$\begin{array}{l}\text { Surface area intervals } \\
\text { (acres) }\end{array}$} \\
\hline & 0 & 0.1 & 0.2 & 0.3 & 0.4 & 0.5 & 0.6 & 0.7 & 0.8 & 0.9 \\
\hline 354 & 111.2 & 111.5 & 111.9 & 112.3 & 112.6 & 112.9 & 113.2 & 113.5 & 113.9 & 114.2 \\
\hline 355 & 114.6 & 115.0 & 115.3 & 115.6 & 116.0 & 116.3 & 116.6 & 117.0 & 117.3 & 117.6 \\
\hline 356 & 117.9 & 118.2 & 118.6 & 118.9 & 119.3 & 119.6 & 120.0 & 120.4 & 120.8 & 121.3 \\
\hline 357 & 121.7 & 122.2 & 122.6 & 123.0 & 123.4 & 123.8 & 124.2 & 124.5 & 124.9 & 125.2 \\
\hline 358 & 125.6 & 126.0 & 126.3 & 126.7 & 127.1 & 127.5 & 127.9 & 128.3 & 128.7 & 129.2 \\
\hline 359 & 129.7 & 130.1 & 130.6 & 131.2 & 131.7 & 132.2 & 132.6 & 133.1 & 133.5 & 133.9 \\
\hline 360 & 134.3 & 134.7 & 135.1 & 135.4 & 135.8 & 136.1 & 136.5 & 136.8 & 137.2 & 137.5 \\
\hline 361 & 137.9 & 138.3 & 138.6 & 139.0 & 139.3 & 139.6 & 140.0 & 140.4 & 140.8 & 141.1 \\
\hline 362 & 141.5 & 141.8 & 142.2 & 142.6 & 143.0 & 143.3 & 143.7 & 144.2 & 144.6 & 145.0 \\
\hline 363 & 145.5 & 145.9 & 146.4 & 146.9 & 147.4 & 147.9 & 148.5 & 149.0 & 149.5 & 150.0 \\
\hline 364 & 150.5 & 151.0 & 151.6 & 152.2 & 152.7 & 153.2 & 153.8 & 154.3 & 154.8 & 155.4 \\
\hline 365 & 156.0 & 156.6 & 157.2 & 157.7 & 158.2 & 158.8 & 159.4 & 160.0 & 160.6 & 161.2 \\
\hline 366 & 161.7 & 162.3 & 162.8 & 163.3 & 163.8 & 164.3 & 164.8 & 165.3 & 165.8 & 166.2 \\
\hline 367 & 166.7 & 167.1 & 167.5 & 167.9 & 168.3 & 168.7 & 169.1 & 169.5 & 169.9 & 170.3 \\
\hline 368 & 170.8 & 171.2 & 171.6 & 171.9 & 172.3 & 172.7 & 173.1 & 173.5 & 173.9 & 174.3 \\
\hline 369 & 174.7 & 175.1 & 175.5 & 175.9 & 176.2 & 176.6 & 177.1 & 177.5 & 178.0 & 178.4 \\
\hline 370 & 178.9 & 179.3 & 179.7 & 180.2 & 180.7 & 181.2 & 181.7 & 182.3 & 182.9 & 183.5 \\
\hline 371 & 184.1 & 184.7 & 185.2 & 185.9 & 186.5 & 187.0 & 187.6 & 188.2 & 188.8 & 189.4 \\
\hline 372 & 189.9 & 190.4 & 190.9 & 191.4 & 192.0 & 192.5 & 193.0 & 193.6 & 194.1 & 194.6 \\
\hline 373 & 195.1 & 195.6 & 196.1 & 196.6 & 197.1 & 197.6 & 198.1 & 198.6 & 199.2 & 199.7 \\
\hline 374 & 200.3 & 200.8 & 201.3 & 201.9 & 202.4 & 202.9 & 203.5 & 204.0 & 204.6 & 205.1 \\
\hline 375 & 205.6 & 206.1 & 206.5 & 207.0 & 207.4 & 207.9 & 208.3 & 208.8 & 209.3 & 209.8 \\
\hline 376 & 210.3 & 210.8 & 211.4 & 211.9 & 212.4 & 212.9 & 213.4 & 213.9 & 214.4 & 214.8 \\
\hline 377 & 215.3 & 215.8 & 216.3 & 216.8 & 217.3 & 217.8 & 218.3 & 218.8 & 219.4 & 219.9 \\
\hline 378 & 220.6 & 221.3 & 221.9 & 222.6 & 223.2 & 223.8 & 224.5 & 225.1 & 225.8 & 226.4 \\
\hline 379 & 227.0 & 227.7 & 228.4 & 229.0 & 229.7 & 230.4 & 231.0 & 231.7 & 232.2 & 232.8 \\
\hline 380 & 233.5 & 234.1 & 234.8 & 235.5 & 236.2 & 236.7 & 237.3 & 237.9 & 238.5 & 239.2 \\
\hline 381 & 239.8 & 240.4 & 241.2 & 241.9 & 242.6 & 243.2 & 243.9 & 244.6 & 245.4 & 246.3 \\
\hline 382 & 247.0 & 247.9 & 248.7 & 249.5 & 250.3 & 251.1 & 251.9 & 252.7 & 253.3 & 254.0 \\
\hline 383 & 254.7 & 255.3 & 255.9 & 256.6 & 257.3 & 258.0 & 258.6 & 259.3 & 260.1 & 260.7 \\
\hline 384 & 261.4 & 262.1 & 262.7 & 263.4 & 264.1 & 264.8 & 265.4 & 266.1 & 266.8 & 267.5 \\
\hline 385 & 268.3 & 269.0 & 269.7 & 270.4 & 271.2 & 271.9 & 272.6 & 273.3 & 273.9 & 274.6 \\
\hline 386 & 275.3 & 275.9 & 276.6 & 277.2 & 277.9 & 278.5 & 279.2 & 279.8 & 280.4 & 281.0 \\
\hline 387 & 281.6 & 282.2 & 282.8 & 283.4 & 284.0 & 284.6 & 285.2 & 285.8 & 286.3 & 286.9 \\
\hline 388 & 287.4 & 288.0 & 288.6 & 289.2 & 289.7 & 290.3 & 290.9 & 291.5 & 292.1 & 292.7 \\
\hline 389 & 293.3 & 293.9 & 294.5 & 295.2 & 295.8 & 296.3 & 296.9 & 297.4 & 297.9 & 298.5 \\
\hline 390 & 299.0 & 299.5 & 300.0 & 300.6 & 301.1 & 301.7 & 302.2 & 302.8 & 303.3 & 303.8 \\
\hline 391 & 304.3 & 304.9 & 305.4 & 306.0 & 306.6 & 307.2 & 307.9 & 308.5 & 309.0 & 309.6 \\
\hline 392 & 310.2 & 310.8 & 311.4 & 312.0 & 312.7 & 313.3 & 313.9 & 314.5 & 315.2 & 315.8 \\
\hline 393 & 316.3 & 316.9 & 317.6 & 318.2 & 318.9 & 319.6 & 320.3 & 321.0 & 321.6 & 322.2 \\
\hline 394 & 322.9 & 323.5 & 324.1 & 324.8 & 325.4 & 326.0 & 326.6 & 327.2 & 327.9 & 328.4 \\
\hline 395 & 328.9 & 329.5 & 330.0 & 330.5 & 331.0 & 331.5 & 332.0 & 332.4 & 332.9 & 333.3 \\
\hline 396 & 333.8 & 334.3 & 334.7 & 335.2 & 335.7 & 336.2 & 336.7 & 337.2 & 337.8 & 338.3 \\
\hline
\end{tabular}


Table 2. Rating table for surface area of the San Antonio Reservoir, California, 2018. - Continued

\begin{tabular}{|c|c|c|c|c|c|c|c|c|c|c|}
\hline \multirow{2}{*}{$\begin{array}{c}\text { Reservoir } \\
\text { stage } \\
\text { (feet) }^{1}\end{array}$} & \multicolumn{10}{|c|}{$\begin{array}{c}\text { Surface area intervals } \\
\text { (acres) }\end{array}$} \\
\hline & 0 & 0.1 & 0.2 & 0.3 & 0.4 & 0.5 & 0.6 & 0.7 & 0.8 & 0.9 \\
\hline 397 & 338.9 & 339.4 & 339.9 & 340.5 & 341.0 & 341.4 & 341.9 & 342.3 & 342.8 & 343.3 \\
\hline 398 & 343.7 & 344.2 & 344.8 & 345.3 & 345.8 & 346.3 & 346.8 & 347.3 & 347.8 & 348.2 \\
\hline 399 & 348.7 & 349.2 & 349.6 & 350.1 & 350.6 & 351.0 & 351.5 & 352.0 & 352.5 & 353.0 \\
\hline 400 & 353.6 & 354.1 & 354.7 & 355.3 & 355.9 & 356.5 & 357.1 & 357.7 & 358.3 & 358.9 \\
\hline 401 & 359.6 & 360.3 & 360.9 & 361.5 & 362.1 & 362.6 & 363.2 & 363.7 & 364.3 & 364.8 \\
\hline 402 & 365.3 & 365.8 & 366.3 & 366.9 & 367.4 & 367.9 & 368.5 & 369.1 & 369.6 & 370.2 \\
\hline 403 & 370.7 & 371.2 & 371.7 & 372.2 & 372.7 & 373.1 & 373.6 & 374.1 & 374.6 & 375.0 \\
\hline 404 & 375.5 & 376.0 & 376.5 & 376.9 & 377.4 & 377.9 & 378.3 & 378.8 & 379.3 & 379.8 \\
\hline 405 & 380.3 & 380.8 & 381.3 & 381.8 & 382.3 & 382.8 & 383.3 & 383.9 & 384.4 & 384.9 \\
\hline 406 & 385.5 & 386.0 & 386.6 & 387.3 & 387.9 & 388.5 & 389.1 & 389.6 & 390.2 & 390.7 \\
\hline 407 & 391.2 & 391.8 & 392.4 & 393.0 & 393.5 & 394.0 & 394.5 & 394.9 & 395.4 & 395.9 \\
\hline 408 & 396.4 & 397.0 & 397.4 & 397.9 & 398.4 & 398.9 & 399.5 & 400.0 & 400.5 & 401.0 \\
\hline 409 & 401.6 & 402.1 & 402.6 & 403.2 & 403.7 & 404.4 & 405.0 & 405.6 & 406.2 & 406.8 \\
\hline 410 & 407.4 & 408.0 & 408.6 & 409.2 & 409.8 & 410.4 & 410.9 & 411.5 & 412.1 & 412.7 \\
\hline 411 & 413.3 & 414.0 & 414.6 & 415.3 & 416.0 & 416.7 & 417.4 & 418.0 & 418.6 & 419.2 \\
\hline 412 & 419.7 & 420.3 & 420.9 & 421.5 & 422.1 & 422.7 & 423.4 & 424.0 & 424.6 & 425.3 \\
\hline 413 & 426.1 & 426.8 & 427.5 & 428.1 & 428.9 & 429.6 & 430.3 & 431.0 & 431.6 & 432.3 \\
\hline 414 & 433.0 & 433.6 & 434.3 & 434.9 & 435.5 & 436.2 & 436.9 & 437.5 & 438.1 & 438.7 \\
\hline 415 & 439.3 & 439.9 & 440.5 & 441.0 & 441.6 & 442.2 & 442.8 & 443.4 & 444.0 & 444.6 \\
\hline 416 & 445.2 & 445.7 & 446.2 & 446.8 & 447.3 & 447.8 & 448.4 & 448.9 & 449.4 & 449.9 \\
\hline 417 & 450.4 & 450.9 & 451.4 & 451.8 & 452.3 & 452.8 & 453.3 & 453.8 & 454.3 & 454.8 \\
\hline 418 & 455.3 & 455.8 & 456.3 & 456.9 & 457.5 & 458.0 & 458.6 & 459.1 & 459.7 & 460.3 \\
\hline 419 & 460.8 & 461.3 & 461.8 & 462.4 & 462.9 & 463.4 & 463.9 & 464.4 & 465.0 & 465.6 \\
\hline 420 & 466.2 & 466.8 & 467.4 & 468.1 & 468.8 & 469.6 & 470.3 & 471.1 & 471.8 & 472.6 \\
\hline 421 & 473.5 & 474.5 & 475.3 & 476.3 & 477.7 & 478.8 & 479.9 & 480.9 & 482.0 & 483.1 \\
\hline 422 & 484.0 & 484.9 & 485.7 & 486.5 & 487.3 & 488.0 & 488.8 & 489.6 & 490.4 & 491.2 \\
\hline 423 & 492.0 & 492.9 & 493.8 & 494.6 & 495.4 & 496.2 & 497.0 & 497.7 & 498.5 & 499.2 \\
\hline 424 & 500.0 & 500.8 & 501.5 & 502.2 & 503.0 & 503.8 & 504.6 & 505.3 & 506.0 & 506.7 \\
\hline 425 & 507.4 & 508.1 & 508.9 & 509.5 & 510.2 & 510.8 & 511.5 & 512.2 & 512.9 & 513.7 \\
\hline 426 & 514.5 & 515.2 & 515.9 & 516.6 & 517.3 & 518.1 & 518.8 & 519.6 & 520.3 & 521.0 \\
\hline 427 & 521.7 & 522.4 & 523.0 & 523.6 & 524.2 & 524.8 & 525.4 & 526.0 & 526.6 & 527.2 \\
\hline 428 & 527.8 & 528.4 & 529.0 & 529.6 & 530.2 & 530.8 & 531.4 & 532.0 & 532.7 & 533.3 \\
\hline 429 & 533.9 & 534.5 & 535.1 & 535.6 & 536.2 & 536.8 & 537.5 & 538.1 & 538.7 & 539.3 \\
\hline 430 & 539.9 & 540.5 & 541.2 & 541.9 & 542.5 & 543.2 & 543.9 & 544.5 & 545.2 & 545.8 \\
\hline 431 & 546.5 & 547.1 & 547.8 & 548.4 & 549.1 & 549.7 & 550.3 & 551.0 & 551.6 & 552.3 \\
\hline 432 & 553.0 & 553.7 & 554.4 & 555.3 & 556.0 & 556.7 & 557.5 & 558.3 & 559.0 & 559.7 \\
\hline 433 & 560.5 & 561.2 & 561.9 & 562.7 & 563.4 & 564.1 & 564.9 & 565.6 & 566.4 & 567.1 \\
\hline 434 & 567.9 & 568.7 & 569.4 & 570.1 & 570.9 & 571.7 & 572.4 & 573.0 & 573.7 & 574.4 \\
\hline 435 & 575.0 & 575.7 & 576.3 & 576.9 & 577.4 & 578.0 & 578.6 & 579.2 & 579.8 & 580.3 \\
\hline 436 & 580.9 & 581.5 & 582.1 & 582.7 & 583.3 & 583.9 & 584.4 & 585.0 & 585.5 & 586.0 \\
\hline 437 & 586.5 & 587.1 & 587.6 & 588.2 & 588.7 & 589.3 & 589.8 & 590.4 & 591.0 & 591.6 \\
\hline 438 & 592.1 & 592.8 & 593.4 & 594.0 & 594.6 & 595.3 & 595.9 & 596.6 & 597.3 & 598.0 \\
\hline 439 & 598.7 & 599.4 & 600.1 & 600.8 & 601.5 & 602.3 & 603.0 & 603.8 & 604.5 & 605.3 \\
\hline
\end{tabular}


Table 2. Rating table for surface area of the San Antonio Reservoir, California, 2018.-Continued

\begin{tabular}{|c|c|c|c|c|c|c|c|c|c|c|}
\hline \multirow{2}{*}{$\begin{array}{c}\text { Reservoir } \\
\text { stage } \\
\text { (feet) }^{1}\end{array}$} & \multicolumn{10}{|c|}{$\begin{array}{l}\text { Surface area intervals } \\
\text { (acres) }\end{array}$} \\
\hline & 0 & 0.1 & 0.2 & 0.3 & 0.4 & 0.5 & 0.6 & 0.7 & 0.8 & 0.9 \\
\hline 440 & 606.1 & 606.8 & 607.6 & 608.3 & 609.0 & 609.8 & 610.6 & 611.3 & 612.0 & 612.7 \\
\hline 441 & 613.4 & 614.1 & 614.8 & 615.5 & 616.2 & 616.9 & 617.6 & 618.3 & 619.0 & 619.7 \\
\hline 442 & 620.5 & 621.2 & 622.0 & 622.8 & 623.5 & 624.3 & 625.1 & 626.0 & 626.8 & 627.6 \\
\hline 443 & 628.6 & 629.5 & 630.4 & 631.3 & 632.2 & 633.1 & 634.0 & 634.8 & 635.7 & 636.5 \\
\hline 444 & 637.3 & 638.0 & 638.8 & 639.6 & 640.4 & 641.3 & 642.2 & 643.0 & 643.9 & 644.7 \\
\hline 445 & 645.5 & 646.2 & 647.0 & 647.8 & 648.5 & 649.3 & 650.0 & 650.8 & 651.6 & 652.4 \\
\hline 446 & 653.1 & 653.8 & 654.5 & 655.1 & 655.8 & 656.5 & 657.2 & 657.9 & 658.6 & 659.5 \\
\hline 447 & 660.3 & 661.0 & 661.7 & 662.4 & 663.1 & 663.7 & 664.4 & 665.1 & 665.8 & 666.5 \\
\hline 448 & 667.2 & 668.0 & 668.7 & 669.4 & 670.2 & 670.9 & 671.7 & 672.5 & 673.3 & 674.1 \\
\hline 449 & 674.9 & 675.7 & 676.5 & 677.3 & 678.2 & 679.1 & 679.9 & 680.8 & 681.7 & 682.5 \\
\hline 450 & 683.4 & 684.3 & 685.2 & 686.1 & 687.0 & 687.8 & 688.7 & 689.6 & 690.5 & 691.4 \\
\hline 451 & 692.3 & 693.2 & 694.1 & 695.0 & 695.8 & 696.7 & 697.5 & 698.3 & 699.2 & 700.0 \\
\hline 452 & 700.8 & 701.5 & 702.3 & 703.0 & 703.7 & 704.4 & 705.1 & 705.8 & 706.5 & 707.2 \\
\hline 453 & 707.9 & 708.5 & 709.1 & 709.7 & 710.3 & 710.9 & 711.5 & 712.1 & 712.6 & 713.2 \\
\hline 454 & 713.8 & 714.3 & 714.9 & 715.4 & 716.0 & 716.6 & 717.1 & 717.7 & 718.3 & 718.9 \\
\hline 455 & 719.5 & 720.2 & 720.9 & 721.7 & 722.5 & 723.4 & 724.4 & 725.5 & 726.5 & 727.6 \\
\hline 456 & 728.8 & 730.0 & 731.1 & 732.2 & 733.2 & 734.2 & 735.1 & 736.0 & 736.9 & 737.7 \\
\hline 457 & 738.5 & 739.3 & 740.1 & 740.9 & 741.7 & 742.5 & 743.2 & 744.0 & 744.8 & 745.6 \\
\hline 458 & 746.4 & 747.2 & 747.9 & 748.8 & 749.6 & 750.4 & 751.2 & 752.0 & 752.8 & 753.6 \\
\hline 459 & 754.4 & 755.2 & 756.0 & 756.8 & 757.6 & 758.5 & 759.3 & 760.1 & 761.0 & 761.8 \\
\hline 460 & 762.7 & 763.6 & 764.5 & 765.4 & 766.3 & 767.3 & 768.2 & 769.1 & 770.0 & 771.0 \\
\hline 461 & 771.9 & 772.9 & 773.8 & 774.8 & 775.7 & 776.7 & 777.6 & 778.5 & 779.4 & 780.3 \\
\hline 462 & 781.2 & 782.1 & 783.0 & 783.8 & 784.7 & 785.5 & 786.3 & 787.2 & 788.0 & 788.9 \\
\hline 463 & 789.7 & 790.6 & 791.4 & 792.3 & 793.1 & 794.0 & 795.0 & 795.8 & 796.7 & 797.5 \\
\hline 464 & 798.3 & 799.1 & 800.0 & 800.8 & 801.7 & 802.5 & 803.3 & 804.1 & 805.0 & 805.8 \\
\hline 465 & 806.7 & 807.5 & 808.4 & 809.2 & 810.0 & 810.9 & 811.7 & 812.5 & 813.2 & 814.0 \\
\hline 466 & 814.8 & 815.5 & 816.3 & 817.0 & 817.8 & 818.5 & 819.3 & 820.0 & 820.8 & 821.6 \\
\hline 467 & 822.3 & 823.1 & 823.8 & 824.6 & 825.3 & 826.1 & 826.9 & 827.7 & 828.4 & 829.2 \\
\hline 468 & 829.9 & 830.7 & 831.4 & 832.1 & 832.8 & 833.5 & 834.2 & 834.9 & 835.6 & 836.2 \\
\hline 469 & 836.9 & 837.6 & 838.3 & 838.9 & 839.7 & 840.4 & 841.1 & 841.8 & 842.5 & 843.2 \\
\hline 470 & 844.0 & 844.7 & 845.5 & 846.2 & 847.0 & 847.8 & 848.6 & 849.5 & 850.3 & 851.2 \\
\hline
\end{tabular}

\footnotetext{
${ }^{1}$ Elevation in feet referenced to NAVD 88.
} 
Table 3. Rating table for storage capacity of the San Antonio Reservoir, California, 2018.

\begin{tabular}{|c|c|c|c|c|c|c|c|c|c|c|}
\hline \multirow{2}{*}{$\begin{array}{c}\text { Reservoir } \\
\text { stage } \\
\text { (feet) }^{1}\end{array}$} & \multicolumn{10}{|c|}{$\begin{array}{c}\text { Storage capacity intervals } \\
\text { (acre-feet) }\end{array}$} \\
\hline & 0 & 0.1 & 0.2 & 0.3 & 0.4 & 0.5 & 0.6 & 0.7 & 0.8 & 0.9 \\
\hline 312 & 0 & 0 & 0 & 0 & 0 & 0 & 0 & 0 & 0 & 0 \\
\hline 313 & 0.0 & 0.1 & 0.1 & 0.1 & 0.1 & 0.1 & 0.2 & 0.2 & 0.2 & 0.2 \\
\hline 314 & 0.3 & 0.3 & 0.3 & 0.4 & 0.4 & 0.4 & 0.5 & 0.5 & 0.5 & 0.6 \\
\hline 315 & 0.6 & 0.6 & 0.7 & 0.7 & 0.8 & 0.8 & 0.8 & 0.9 & 0.9 & 1.0 \\
\hline 316 & 1.0 & 1.1 & 1.2 & 1.2 & 1.3 & 1.4 & 1.5 & 1.6 & 1.7 & 1.8 \\
\hline 317 & 1.9 & 2.0 & 2.1 & 2.3 & 2.4 & 2.5 & 2.7 & 2.8 & 3.0 & 3.1 \\
\hline 318 & 3.3 & 3.4 & 3.6 & 3.8 & 4.0 & 4.2 & 4.4 & 4.6 & 4.8 & 5.0 \\
\hline 319 & 5.2 & 5.4 & 5.7 & 5.9 & 6.1 & 6.4 & 6.6 & 6.9 & 7.2 & 7.4 \\
\hline 320 & 7.7 & 8.0 & 8.3 & 8.6 & 8.9 & 9.2 & 9.5 & 9.8 & 10.1 & 10.4 \\
\hline 321 & 10.7 & 11.0 & 11.3 & 11.7 & 12.0 & 12.3 & 12.7 & 13.0 & 13.4 & 13.8 \\
\hline 322 & 14.1 & 14.5 & 14.9 & 15.3 & 15.7 & 16.1 & 16.5 & 17.0 & 17.4 & 17.8 \\
\hline 323 & 18.3 & 18.8 & 19.2 & 19.7 & 20.3 & 20.8 & 21.4 & 22.0 & 22.6 & 23.2 \\
\hline 324 & 23.9 & 24.5 & 25.2 & 25.9 & 26.7 & 27.4 & 28.2 & 29.0 & 29.8 & 30.7 \\
\hline 325 & 31.5 & 32.4 & 33.4 & 34.3 & 35.3 & 36.3 & 37.4 & 38.5 & 39.6 & 40.7 \\
\hline 326 & 41.8 & 43.0 & 44.2 & 45.4 & 46.6 & 47.8 & 49.1 & 50.3 & 51.6 & 52.9 \\
\hline 327 & 54.2 & 55.5 & 56.9 & 58.2 & 59.6 & 61.0 & 62.4 & 63.8 & 65.2 & 66.6 \\
\hline 328 & 68.1 & 69.5 & 71.0 & 72.5 & 74.0 & 75.5 & 77.0 & 78.6 & 80.1 & 81.7 \\
\hline 329 & 83.3 & 84.9 & 86.6 & 88.2 & 89.9 & 91.5 & 93.2 & 94.9 & 96.6 & 98.4 \\
\hline 330 & 100 & 102 & 104 & 105 & 107 & 109 & 111 & 113 & 115 & 117 \\
\hline 331 & 119 & 121 & 123 & 125 & 127 & 129 & 131 & 133 & 135 & 137 \\
\hline 332 & 140 & 142 & 144 & 146 & 148 & 151 & 153 & 155 & 158 & 160 \\
\hline 333 & 162 & 165 & 167 & 169 & 172 & 174 & 177 & 179 & 182 & 184 \\
\hline 334 & 187 & 190 & 192 & 195 & 197 & 200 & 203 & 205 & 208 & 211 \\
\hline 335 & 214 & 216 & 219 & 222 & 225 & 228 & 231 & 233 & 236 & 239 \\
\hline 336 & 242 & 245 & 248 & 251 & 254 & 257 & 260 & 263 & 267 & 270 \\
\hline 337 & 273 & 276 & 279 & 282 & 286 & 289 & 292 & 296 & 299 & 302 \\
\hline 338 & 306 & 309 & 313 & 316 & 320 & 323 & 327 & 330 & 334 & 338 \\
\hline 339 & 341 & 345 & 349 & 352 & 356 & 360 & 364 & 368 & 371 & 375 \\
\hline 340 & 379 & 383 & 387 & 391 & 395 & 399 & 403 & 407 & 412 & 416 \\
\hline 341 & 420 & 424 & 428 & 432 & 437 & 441 & 445 & 450 & 454 & 459 \\
\hline 342 & 463 & 468 & 473 & 477 & 482 & 487 & 492 & 497 & 502 & 508 \\
\hline 343 & 513 & 518 & 524 & 529 & 535 & 541 & 547 & 553 & 559 & 565 \\
\hline 344 & 571 & 577 & 583 & 590 & 596 & 603 & 609 & 616 & 623 & 629 \\
\hline 345 & 636 & 643 & 650 & 657 & 664 & 671 & 679 & 686 & 693 & 701 \\
\hline 346 & 708 & 716 & 723 & 731 & 738 & 746 & 754 & 762 & 770 & 778 \\
\hline 347 & 786 & 794 & 802 & 810 & 818 & 826 & 835 & 843 & 851 & 860 \\
\hline 348 & 868 & 877 & 885 & 894 & 903 & 911 & 920 & 929 & 938 & 947 \\
\hline 349 & 956 & 965 & 974 & 983 & 993 & 1,002 & 1,011 & 1,021 & 1,030 & 1,040 \\
\hline 350 & 1,049 & 1,059 & 1,068 & 1,078 & 1,088 & 1,097 & 1,107 & 1,117 & 1,127 & 1,137 \\
\hline 351 & 1,147 & 1,157 & 1,167 & 1,177 & 1,187 & 1,198 & 1,208 & 1,218 & 1,228 & 1,239 \\
\hline 352 & 1,249 & 1,260 & 1,270 & 1,280 & 1,291 & 1,302 & 1,312 & 1,323 & 1,333 & 1,344 \\
\hline 353 & 1,355 & 1,366 & 1,377 & 1,387 & 1,398 & 1,409 & 1,420 & 1,431 & 1,442 & 1,453 \\
\hline
\end{tabular}


Table 3. Rating table for storage capacity of the San Antonio Reservoir, California, 2018.—Continued

\begin{tabular}{|c|c|c|c|c|c|c|c|c|c|c|}
\hline \multirow{2}{*}{$\begin{array}{c}\text { Reservoir } \\
\text { stage } \\
\text { (feet) }^{1}\end{array}$} & \multicolumn{10}{|c|}{$\begin{array}{c}\text { Storage capacity intervals } \\
\text { (acre-feet) }\end{array}$} \\
\hline & 0 & 0.1 & 0.2 & 0.3 & 0.4 & 0.5 & 0.6 & 0.7 & 0.8 & 0.9 \\
\hline 354 & 1,465 & 1,476 & 1,487 & 1,498 & 1,509 & 1,521 & 1,532 & 1,543 & 1,555 & 1,566 \\
\hline 355 & 1,578 & 1,589 & 1,601 & 1,612 & 1,624 & 1,635 & 1,647 & 1,659 & 1,670 & 1,682 \\
\hline 356 & 1,694 & 1,706 & 1,718 & 1,730 & 1,742 & 1,753 & 1,765 & 1,778 & 1,790 & 1,802 \\
\hline 357 & 1,814 & 1,826 & 1,838 & 1,851 & 1,863 & 1,875 & 1,888 & 1,900 & 1,913 & 1,925 \\
\hline 358 & 1,938 & 1,950 & 1,963 & 1,976 & 1,988 & 2,001 & 2,014 & 2,027 & 2,040 & 2,053 \\
\hline 359 & 2,066 & 2,079 & 2,092 & 2,105 & 2,118 & 2,131 & 2,144 & 2,158 & 2,171 & 2,184 \\
\hline 360 & 2,198 & 2,211 & 2,225 & 2,238 & 2,252 & 2,266 & 2,279 & 2,293 & 2,307 & 2,320 \\
\hline 361 & 2,334 & 2,348 & 2,362 & 2,376 & 2,390 & 2,404 & 2,418 & 2,432 & 2,446 & 2,460 \\
\hline 362 & 2,474 & 2,488 & 2,502 & 2,517 & 2,531 & 2,545 & 2,560 & 2,574 & 2,589 & 2,603 \\
\hline 363 & 2,618 & 2,632 & 2,647 & 2,662 & 2,676 & 2,691 & 2,706 & 2,721 & 2,736 & 2,751 \\
\hline 364 & 2,766 & 2,781 & 2,796 & 2,811 & 2,827 & 2,842 & 2,857 & 2,873 & 2,888 & 2,904 \\
\hline 365 & 2,919 & 2,935 & 2,951 & 2,967 & 2,982 & 2,998 & 3,014 & 3,030 & 3,046 & 3,062 \\
\hline 366 & 3,079 & 3,095 & 3,111 & 3,127 & 3,144 & 3,160 & 3,177 & 3,193 & 3,210 & 3,226 \\
\hline 367 & 3,243 & 3,260 & 3,277 & 3,293 & 3,310 & 3,327 & 3,344 & 3,361 & 3,378 & 3,395 \\
\hline 368 & 3,412 & 3,429 & 3,446 & 3,463 & 3,481 & 3,498 & 3,515 & 3,533 & 3,550 & 3,567 \\
\hline 369 & 3,585 & 3,602 & 3,620 & 3,638 & 3,655 & 3,673 & 3,691 & 3,708 & 3,726 & 3,744 \\
\hline 370 & 3,762 & 3,780 & 3,798 & 3,816 & 3,834 & 3,852 & 3,870 & 3,888 & 3,907 & 3,925 \\
\hline 371 & 3,943 & 3,962 & 3,980 & 3,999 & 4,018 & 4,036 & 4,055 & 4,074 & 4,093 & 4,112 \\
\hline 372 & 4,131 & 4,150 & 4,169 & 4,188 & 4,207 & 4,226 & 4,246 & 4,265 & 4,284 & 4,304 \\
\hline 373 & 4,323 & 4,343 & 4,363 & 4,382 & 4,402 & 4,422 & 4,442 & 4,461 & 4,481 & 4,501 \\
\hline 374 & 4,521 & 4,541 & 4,562 & 4,582 & 4,602 & 4,622 & 4,643 & 4,663 & 4,683 & 4,704 \\
\hline 375 & 4,725 & 4,745 & 4,766 & 4,786 & 4,807 & 4,828 & 4,849 & 4,870 & 4,891 & 4,912 \\
\hline 376 & 4,933 & 4,954 & 4,975 & 4,996 & 5,017 & 5,039 & 5,060 & 5,081 & 5,103 & 5,124 \\
\hline 377 & 5,146 & 5,167 & 5,189 & 5,211 & 5,232 & 5,254 & 5,276 & 5,298 & 5,320 & 5,342 \\
\hline 378 & 5,364 & 5,386 & 5,408 & 5,430 & 5,453 & 5,475 & 5,498 & 5,520 & 5,543 & 5,565 \\
\hline 379 & 5,588 & 5,611 & 5,634 & 5,657 & 5,680 & 5,703 & 5,726 & 5,749 & 5,772 & 5,795 \\
\hline 380 & 5,819 & 5,842 & 5,866 & 5,889 & 5,913 & 5,936 & 5,960 & 5,984 & 6,008 & 6,032 \\
\hline 381 & 6,056 & 6,080 & 6,104 & 6,128 & 6,152 & 6,177 & 6,201 & 6,225 & 6,250 & 6,275 \\
\hline 382 & 6,299 & 6,324 & 6,349 & 6,374 & 6,399 & 6,424 & 6,449 & 6,475 & 6,500 & 6,525 \\
\hline 383 & 6,551 & 6,576 & 6,602 & 6,628 & 6,653 & 6,679 & 6,705 & 6,731 & 6,757 & 6,783 \\
\hline 384 & 6,809 & 6,835 & 6,862 & 6,888 & 6,914 & 6,941 & 6,967 & 6,994 & 7,021 & 7,047 \\
\hline 385 & 7,074 & 7,101 & 7,128 & 7,155 & 7,182 & 7,209 & 7,237 & 7,264 & 7,291 & 7,319 \\
\hline 386 & 7,346 & 7,374 & 7,402 & 7,429 & 7,457 & 7,485 & 7,513 & 7,541 & 7,569 & 7,597 \\
\hline 387 & 7,625 & 7,653 & 7,682 & 7,710 & 7,738 & 7,767 & 7,795 & 7,824 & 7,853 & 7,881 \\
\hline 388 & 7,910 & 7,939 & 7,968 & 7,997 & 8,026 & 8,055 & 8,084 & 8,113 & 8,142 & 8,171 \\
\hline 389 & 8,201 & 8,230 & 8,260 & 8,289 & 8,319 & 8,348 & 8,378 & 8,408 & 8,438 & 8,467 \\
\hline 390 & 8,497 & 8,527 & 8,557 & 8,587 & 8,617 & 8,648 & 8,678 & 8,708 & 8,738 & 8,769 \\
\hline 391 & 8,799 & 8,830 & 8,860 & 8,891 & 8,921 & 8,952 & 8,983 & 9,014 & 9,045 & 9,076 \\
\hline 392 & 9,107 & 9,138 & 9,169 & 9,200 & 9,231 & 9,263 & 9,294 & 9,326 & 9,357 & 9,389 \\
\hline 393 & 9,420 & 9,452 & 9,484 & 9,516 & 9,547 & 9,579 & 9,611 & 9,644 & 9,676 & 9,708 \\
\hline 394 & 9,740 & 9,773 & 9,805 & 9,837 & 9,870 & 9,903 & 9,935 & 9,968 & 10,001 & 10,034 \\
\hline 395 & 10,067 & 10,099 & 10,132 & 10,166 & 10,199 & 10,232 & 10,265 & 10,298 & 10,332 & 10,365 \\
\hline 396 & 10,398 & 10,432 & 10,465 & 10,499 & 10,532 & 10,566 & 10,600 & 10,633 & 10,667 & 10,701 \\
\hline
\end{tabular}


Table 3. Rating table for storage capacity of the San Antonio Reservoir, California, 2018.-Continued

\begin{tabular}{|c|c|c|c|c|c|c|c|c|c|c|}
\hline \multirow{2}{*}{$\begin{array}{c}\text { Reservoir } \\
\text { stage } \\
\text { (feet) }^{1}\end{array}$} & \multicolumn{10}{|c|}{$\begin{array}{l}\text { Storage capacity intervals } \\
\text { (acre-feet) }\end{array}$} \\
\hline & 0 & 0.1 & 0.2 & 0.3 & 0.4 & 0.5 & 0.6 & 0.7 & 0.8 & 0.9 \\
\hline 397 & 10,735 & 10,769 & 10,803 & 10,837 & 10,871 & 10,905 & 10,939 & 10,973 & 11,008 & 11,042 \\
\hline 398 & 11,076 & 11,111 & 11,145 & 11,180 & 11,214 & 11,249 & 11,284 & 11,318 & 11,353 & 11,388 \\
\hline 399 & 11,423 & 11,458 & 11,493 & 11,528 & 11,563 & 11,598 & 11,633 & 11,668 & 11,704 & 11,739 \\
\hline 400 & 11,774 & 11,810 & 11,845 & 11,881 & 11,916 & 11,952 & 11,988 & 12,023 & 12,059 & 12,095 \\
\hline 401 & 12,131 & 12,167 & 12,203 & 12,239 & 12,275 & 12,312 & 12,348 & 12,384 & 12,421 & 12,457 \\
\hline 402 & 12,494 & 12,530 & 12,567 & 12,604 & 12,641 & 12,677 & 12,714 & 12,751 & 12,788 & 12,825 \\
\hline 403 & 12,862 & 12,899 & 12,936 & 12,974 & 13,011 & 13,048 & 13,086 & 13,123 & 13,160 & 13,198 \\
\hline 404 & 13,235 & 13,273 & 13,311 & 13,348 & 13,386 & 13,424 & 13,462 & 13,500 & 13,538 & 13,576 \\
\hline 405 & 13,614 & 13,652 & 13,690 & 13,728 & 13,766 & 13,805 & 13,843 & 13,881 & 13,920 & 13,958 \\
\hline 406 & 13,997 & 14,035 & 14,074 & 14,113 & 14,151 & 14,190 & 14,229 & 14,268 & 14,307 & 14,346 \\
\hline 407 & 14,385 & 14,425 & 14,464 & 14,503 & 14,542 & 14,582 & 14,621 & 14,661 & 14,700 & 14,740 \\
\hline 408 & 14,780 & 14,819 & 14,859 & 14,899 & 14,939 & 14,979 & 15,019 & 15,059 & 15,099 & 15,139 \\
\hline 409 & 15,179 & 15,219 & 15,259 & 15,300 & 15,340 & 15,380 & 15,421 & 15,461 & 15,502 & 15,543 \\
\hline 410 & 15,584 & 15,624 & 15,665 & 15,706 & 15,747 & 15,788 & 15,829 & 15,870 & 15,912 & 15,953 \\
\hline 411 & 15,994 & 16,036 & 16,077 & 16,119 & 16,160 & 16,202 & 16,244 & 16,285 & 16,327 & 16,369 \\
\hline 412 & 16,411 & 16,453 & 16,495 & 16,537 & 16,580 & 16,622 & 16,664 & 16,707 & 16,749 & 16,792 \\
\hline 413 & 16,834 & 16,877 & 16,920 & 16,962 & 17,005 & 17,048 & 17,091 & 17,134 & 17,178 & 17,221 \\
\hline 414 & 17,264 & 17,307 & 17,351 & 17,394 & 17,438 & 17,482 & 17,525 & 17,569 & 17,613 & 17,657 \\
\hline 415 & 17,701 & 17,745 & 17,789 & 17,833 & 17,877 & 17,921 & 17,965 & 18,010 & 18,054 & 18,099 \\
\hline 416 & 18,143 & 18,188 & 18,232 & 18,277 & 18,322 & 18,367 & 18,411 & 18,456 & 18,501 & 18,546 \\
\hline 417 & 18,591 & 18,636 & 18,681 & 18,727 & 18,772 & 18,817 & 18,862 & 18,908 & 18,953 & 18,999 \\
\hline 418 & 19,044 & 19,090 & 19,135 & 19,181 & 19,227 & 19,273 & 19,319 & 19,364 & 19,410 & 19,456 \\
\hline 419 & 19,503 & 19,549 & 19,595 & 19,641 & 19,687 & 19,734 & 19,780 & 19,827 & 19,873 & 19,920 \\
\hline 420 & 19,966 & 20,013 & 20,060 & 20,106 & 20,153 & 20,200 & 20,247 & 20,294 & 20,342 & 20,389 \\
\hline 421 & 20,436 & 20,484 & 20,531 & 20,579 & 20,627 & 20,675 & 20,723 & 20,771 & 20,819 & 20,867 \\
\hline 422 & 20,916 & 20,964 & 21,013 & 21,061 & 21,110 & 21,159 & 21,208 & 21,257 & 21,306 & 21,355 \\
\hline 423 & 21,404 & 21,453 & 21,503 & 21,552 & 21,602 & 21,651 & 21,701 & 21,751 & 21,801 & 21,851 \\
\hline 424 & 21,901 & 21,951 & 22,001 & 22,051 & 22,101 & 22,152 & 22,202 & 22,253 & 22,303 & 22,354 \\
\hline 425 & 22,405 & 22,455 & 22,506 & 22,557 & 22,608 & 22,659 & 22,711 & 22,762 & 22,813 & 22,864 \\
\hline 426 & 22,916 & 22,967 & 23,019 & 23,071 & 23,122 & 23,174 & 23,226 & 23,278 & 23,330 & 23,382 \\
\hline 427 & 23,434 & 23,487 & 23,539 & 23,591 & 23,644 & 23,696 & 23,749 & 23,801 & 23,854 & 23,907 \\
\hline 428 & 23,959 & 24,012 & 24,065 & 24,118 & 24,171 & 24,224 & 24,277 & 24,331 & 24,384 & 24,437 \\
\hline 429 & 24,491 & 24,544 & 24,598 & 24,651 & 24,705 & 24,758 & 24,812 & 24,866 & 24,920 & 24,974 \\
\hline 430 & 25,028 & 25,082 & 25,136 & 25,190 & 25,244 & 25,299 & 25,353 & 25,408 & 25,462 & 25,517 \\
\hline 431 & 25,571 & 25,626 & 25,681 & 25,736 & 25,791 & 25,845 & 25,901 & 25,956 & 26,011 & 26,066 \\
\hline 432 & 26,121 & 26,177 & 26,232 & 26,288 & 26,343 & 26,399 & 26,455 & 26,510 & 26,566 & 26,622 \\
\hline 433 & 26,678 & 26,735 & 26,791 & 26,847 & 26,903 & 26,960 & 27,016 & 27,073 & 27,129 & 27,186 \\
\hline 434 & 27,243 & 27,300 & 27,357 & 27,414 & 27,471 & 27,528 & 27,585 & 27,643 & 27,700 & 27,757 \\
\hline 435 & 27,815 & 27,872 & 27,930 & 27,988 & 28,045 & 28,103 & 28,161 & 28,219 & 28,277 & 28,335 \\
\hline 436 & 28,393 & 28,451 & 28,510 & 28,568 & 28,626 & 28,685 & 28,743 & 28,801 & 28,860 & 28,919 \\
\hline 437 & 28,977 & 29,036 & 29,095 & 29,154 & 29,212 & 29,271 & 29,330 & 29,389 & 29,448 & 29,508 \\
\hline 438 & 29,567 & 29,626 & 29,685 & 29,745 & 29,804 & 29,864 & 29,923 & 29,983 & 30,043 & 30,103 \\
\hline 439 & 30,163 & 30,222 & 30,282 & 30,343 & 30,403 & 30,463 & 30,523 & 30,584 & 30,644 & 30,705 \\
\hline
\end{tabular}


Table 3. Rating table for storage capacity of the San Antonio Reservoir, California, 2018.-Continued

\begin{tabular}{|c|c|c|c|c|c|c|c|c|c|c|}
\hline \multirow{2}{*}{$\begin{array}{c}\text { Reservoir } \\
\text { stage } \\
\text { (feet) }^{1}\end{array}$} & \multicolumn{10}{|c|}{$\begin{array}{c}\text { Storage capacity intervals } \\
\text { (acre-feet) }\end{array}$} \\
\hline & 0 & 0.1 & 0.2 & 0.3 & 0.4 & 0.5 & 0.6 & 0.7 & 0.8 & 0.9 \\
\hline 440 & 30,765 & 30,826 & 30,887 & 30,947 & 31,008 & 31,069 & 31,130 & 31,192 & 31,253 & 31,314 \\
\hline 441 & 31,375 & 31,437 & 31,498 & 31,560 & 31,621 & 31,683 & 31,745 & 31,807 & 31,869 & 31,931 \\
\hline 442 & 31,993 & 32,055 & 32,117 & 32,179 & 32,242 & 32,304 & 32,366 & 32,429 & 32,492 & 32,555 \\
\hline 443 & 32,617 & 32,680 & 32,743 & 32,806 & 32,870 & 32,933 & 32,996 & 33,060 & 33,123 & 33,187 \\
\hline 444 & 33,251 & 33,315 & 33,379 & 33,443 & 33,507 & 33,571 & 33,635 & 33,699 & 33,764 & 33,828 \\
\hline 445 & 33,893 & 33,957 & 34,022 & 34,087 & 34,152 & 34,216 & 34,281 & 34,347 & 34,412 & 34,477 \\
\hline 446 & 34,542 & 34,608 & 34,673 & 34,739 & 34,804 & 34,870 & 34,936 & 35,001 & 35,067 & 35,133 \\
\hline 447 & 35,199 & 35,265 & 35,331 & 35,398 & 35,464 & 35,530 & 35,597 & 35,663 & 35,730 & 35,797 \\
\hline 448 & 35,863 & 35,930 & 35,997 & 36,064 & 36,131 & 36,198 & 36,265 & 36,332 & 36,400 & 36,467 \\
\hline 449 & 36,535 & 36,602 & 36,670 & 36,738 & 36,805 & 36,873 & 36,941 & 37,009 & 37,078 & 37,146 \\
\hline 450 & 37,214 & 37,283 & 37,351 & 37,420 & 37,488 & 37,557 & 37,626 & 37,695 & 37,764 & 37,833 \\
\hline 451 & 37,902 & 37,972 & 38,041 & 38,111 & 38,180 & 38,250 & 38,320 & 38,390 & 38,459 & 38,529 \\
\hline 452 & 38,600 & 38,670 & 38,740 & 38,810 & 38,881 & 38,951 & 39,022 & 39,092 & 39,163 & 39,233 \\
\hline 453 & 39,304 & 39,375 & 39,446 & 39,517 & 39,588 & 39,659 & 39,730 & 39,801 & 39,873 & 39,944 \\
\hline 454 & 40,015 & 40,087 & 40,158 & 40,230 & 40,302 & 40,373 & 40,445 & 40,517 & 40,588 & 40,660 \\
\hline 455 & 40,732 & 40,804 & 40,876 & 40,949 & 41,021 & 41,093 & 41,166 & 41,238 & 41,311 & 41,384 \\
\hline 456 & 41,456 & 41,529 & 41,603 & 41,676 & 41,749 & 41,823 & 41,896 & 41,970 & 42,043 & 42,117 \\
\hline 457 & 42,191 & 42,265 & 42,339 & 42,413 & 42,487 & 42,561 & 42,636 & 42,710 & 42,785 & 42,859 \\
\hline 458 & 42,934 & 43,009 & 43,083 & 43,158 & 43,233 & 43,308 & 43,383 & 43,459 & 43,534 & 43,609 \\
\hline 459 & 43,685 & 43,760 & 43,836 & 43,911 & 43,987 & 44,063 & 44,139 & 44,215 & 44,291 & 44,367 \\
\hline 460 & 44,443 & 44,520 & 44,596 & 44,673 & 44,749 & 44,826 & 44,903 & 44,980 & 45,057 & 45,134 \\
\hline 461 & 45,211 & 45,289 & 45,366 & 45,443 & 45,521 & 45,599 & 45,676 & 45,754 & 45,832 & 45,910 \\
\hline 462 & 45,988 & 46,067 & 46,145 & 46,223 & 46,302 & 46,380 & 46,459 & 46,538 & 46,616 & 46,695 \\
\hline 463 & 46,774 & 46,853 & 46,932 & 47,012 & 47,091 & 47,170 & 47,250 & 47,329 & 47,409 & 47,489 \\
\hline 464 & 47,569 & 47,649 & 47,729 & 47,809 & 47,889 & 47,969 & 48,049 & 48,130 & 48,210 & 48,291 \\
\hline 465 & 48,372 & 48,452 & 48,533 & 48,614 & 48,695 & 48,776 & 48,857 & 48,939 & 49,020 & 49,101 \\
\hline 466 & 49,183 & 49,264 & 49,346 & 49,428 & 49,509 & 49,591 & 49,673 & 49,755 & 49,837 & 49,919 \\
\hline 467 & 50,002 & 50,084 & 50,166 & 50,249 & 50,331 & 50,414 & 50,497 & 50,579 & 50,662 & 50,745 \\
\hline 468 & 50,828 & 50,911 & 50,994 & 51,078 & 51,161 & 51,244 & 51,328 & 51,411 & 51,495 & 51,578 \\
\hline 469 & 51,662 & 51,746 & 51,830 & 51,914 & 51,998 & 52,082 & 52,166 & 52,250 & 52,334 & 52,418 \\
\hline 470 & 52,503 & 52,587 & 52,672 & 52,756 & 52,841 & 52,926 & 53,011 & 53,096 & 53,181 & 53,266 \\
\hline llway & meas & at 470. & eet Nor & Americ & Tertical & tum of & (NA) & 8). & & \\
\hline
\end{tabular}



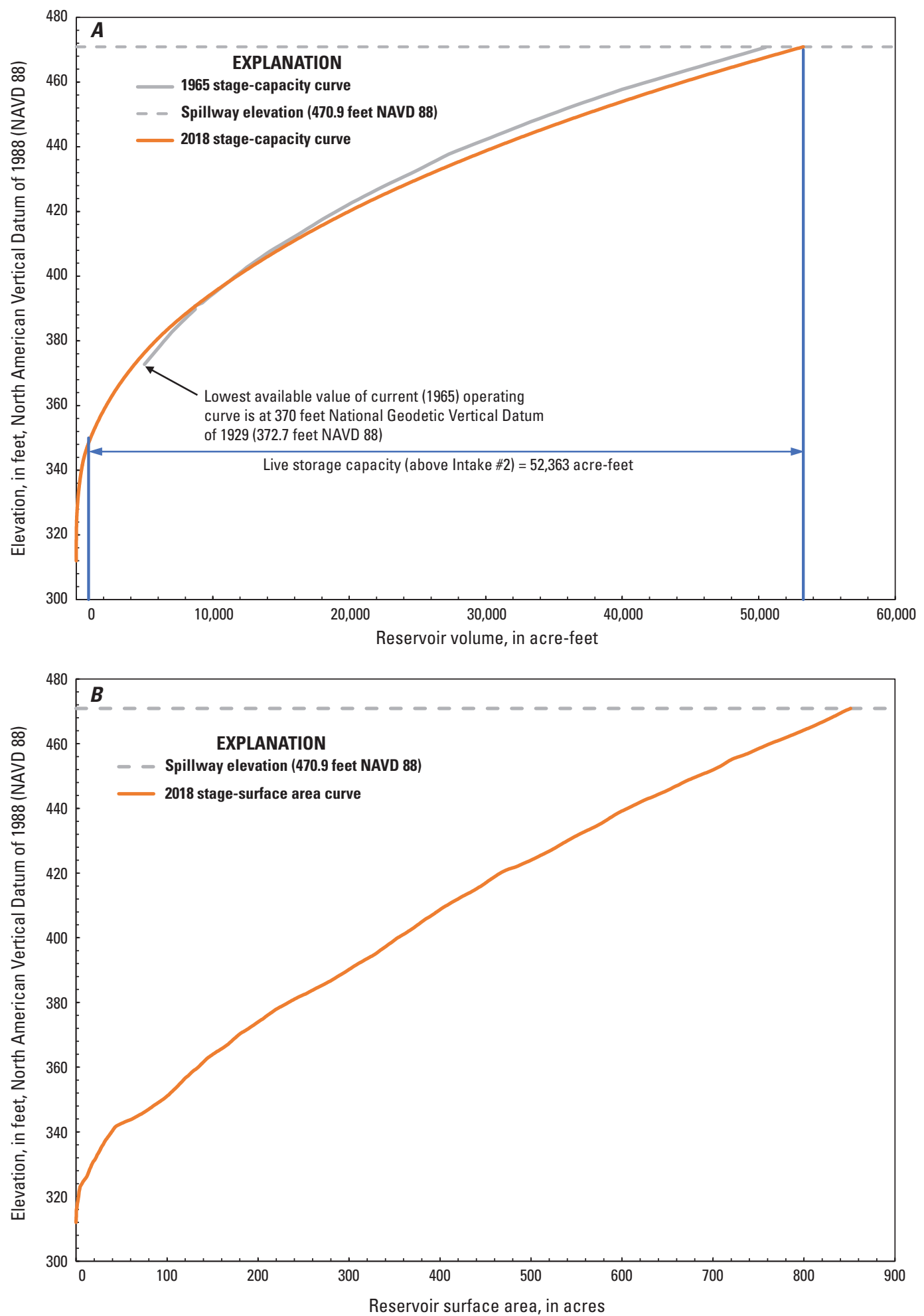

Figure 9. A, stage-capacity curves for 1965 and 2018 with live storage capacity above Intake \#2 indicated, and $B$, stage-surface area curve for 2018, San Antonio Reservoir, California. 
Comparison of the 2018 and 1965 capacity estimates indicates that the capacity had increased from 50,500 acre-ft in 1965 (the year when the dam became fully operational) to 53,266 acre-ft in 2018 (an increase of 5.5 percent). However, because there is no obvious mechanism for the storage capacity to increase in the reservoir, this increase is most likely due to survey measurement uncertainty and errors in the original survey. Direct comparison of the stage-capacity curves between 1965 and 2018 indicates decreased capacity in the lower elevation parts of the reservoir and increased capacity at higher elevations (fig. 9). The decreased capacity in the lower elevation parts of the reservoir was observed independently through bathymetric measurements around the intake structures. Sedimentation near the intake structure has buried Intake \#1. Intake \#2 was the lowest operational intake, which means that all storage below Intake \#2 was considered dead storage at the time of the 2018 survey. Live storage above Intake \#2 was 52,363 acre-ft at the time of the survey. Table 4 summarizes the elevation and reservoir storage capacity above each intake.

\section{Survey Error Estimate}

The total storage capacity error for this survey was estimated to be approximately plus or minus $140 \mathrm{acre}-\mathrm{ft}$. To arrive at this estimate, the authors divided the 852.3-acre survey area into three uncertainty zones (sections). The first

Table 4. Summary of elevation and reservoir storage capacity above each intake, San Antonio Reservoir, California, 2018.

[ft, feet; acre-ft, acre feet; NAVD 88, North American Vertical Datum of 1988; NGVD 29, National Geodic Vertical Datum of 1929]

\begin{tabular}{cccc}
\hline \multirow{2}{*}{ Intake } & \multicolumn{2}{c}{$\begin{array}{c}\text { Elevation' } \\
\text { (ft) }\end{array}$} & $\begin{array}{c}\text { Capacity } \\
\text { above intake } \\
\text { (acre-ft) }\end{array}$ \\
\cline { 2 - 3 } & NAVD 88 & NGVD 29 & 53,262 \\
${ }^{3} 2$ & 318.40 & 315.65 & 52,363 \\
3 & 348.40 & 345.65 & 47,813 \\
4 & 378.40 & 375.65 & 38,327 \\
5 & 408.40 & 405.65 & 23,462 \\
\hline
\end{tabular}

'Elevation of intake from engineering drawing of outlet works' intake structure (Bechtel Corporation, 1963b).

${ }^{2}$ Calculated from 2018 reservoir survey; total capacity was measured at 53,266 acre-ft.

${ }^{3}$ Intake \#2 was the lowest level operational intake at the time of the 2018 survey. section was the area measured using GNSS-RTN ground surveying, which likely had the largest error. Although the point measurements are typically accurate within $1-2 \mathrm{~cm}$, due to large spacing between point measurements, particularly in areas with heavy vegetation, the elevation for much of the area was estimated using interpolation between point measurements. Therefore, we estimate that the elevation in this area, which is about 50 acres, was within plus or minus $1.0 \mathrm{ft}$ of true elevation. The second highest error would be for areas that were hard-to-reach using boat-mounted LiDAR, which were mostly in small draws and tributary drainage areas. These areas included about 35 acres and we estimate that measurements were within plus or minus $0.5 \mathrm{ft}$ of true elevation. The remainder of the reservoir (767.3 acres) was surveyed with high-resolution multibeam and LiDAR, often with many measurements (average of about 700 points per $\mathrm{m}^{2}$ or 65 points per square foot, $\mathrm{ft}^{2}$ ), so we estimate that the elevation for those areas was likely within plus or minus $0.1 \mathrm{ft}$ of true elevation. Combined, this results in an average error of plus or minus $0.16 \mathrm{ft}$ across the entire reservoir surface or plus or minus 140 acre-ft.

\section{Bed-Material Composition}

Particle-size distribution analysis of bed-material samples collected in the San Antonio Reservoir showed that the bed material was predominately composed of silt (69 percent), followed by clay ( 21 percent), and sand (10 percent). Tables 5 and 6 provide summary data and particle-size distribution data for the 35 samples collected. With the exception of two samples (sites 10 and 19; table 6), Gravel never composed more than half of a percent of any sample. Figure 7 shows the location of the bed-material samples and the median particle size $\left(D_{50}\right)$ is indicated by circle size. The cumulative particlesize distributions of all bed-material samples collected during the survey campaign are summarized in figure 10.

There was a slight gradational trend from coarse to finer material from the head of the reservoir (near San Antonio Creek delta) to the lower end of the reservoir (at the dam). Figure 11 shows longitudinal profiles of the bed elevation and median particle size in 2018. The bed-elevation data were extracted along the pre-dam channel of San Antonio Creek. This type of gradation is indicative of a depositional environment and is common for reservoirs due to the longer settling time of finer particles; fines (silt and clay) can therefore travel in suspension from the source (typically bank erosion or inflowing creeks) to closer to the dam and spillway before settling to the bottom. 
Table 5. Bed-material samples data including location, depth, and mass, San Antonio Reservoir, California.

[mm/dd/yyyy, month/day/year; PST, Pacific Standard Time; hh:mm, hours:minutes; ft, feet; g, gram; Y, yes; N, no]

\begin{tabular}{|c|c|c|c|c|c|c|c|c|}
\hline Site & $\begin{array}{l}\text { Sample date } \\
\text { (mm/dd/yyyy) }\end{array}$ & $\begin{array}{c}\text { Time } \\
\text { (PST) } \\
\text { (hh:mm) }\end{array}$ & $\begin{array}{l}\text { Latitude } \\
\text { (decimal } \\
\text { degrees) }\end{array}$ & $\begin{array}{l}\text { Longitude } \\
\text { (decimal } \\
\text { degrees) }\end{array}$ & $\begin{array}{l}\text { Depth } \\
\text { (ft) }\end{array}$ & $\begin{array}{c}\text { Shells } \\
\text { present? }\end{array}$ & $\begin{array}{l}\text { Organics } \\
\text { present? }\end{array}$ & $\begin{array}{c}\text { Total sample weight } \\
\text { (without shells and organics) } \\
\text { (g) }\end{array}$ \\
\hline 1 & $4 / 30 / 2018$ & $10: 22$ & 37.586 & -121.825 & 66.1 & $\mathrm{Y}$ & $\mathrm{N}$ & 100.15 \\
\hline 2 & $4 / 30 / 2018$ & 09:22 & 37.589 & -121.816 & 35.0 & Y & $\mathrm{N}$ & 108.17 \\
\hline 3 & $4 / 30 / 2018$ & 09:14 & 37.589 & -121.813 & 26.4 & Y & $\mathrm{N}$ & 162.37 \\
\hline 4 & $4 / 30 / 2018$ & 09:08 & 37.588 & -121.812 & 20.9 & Y & Y & 140.55 \\
\hline 5 & $4 / 30 / 2018$ & $08: 43$ & 37.588 & -121.810 & 16.6 & $\mathrm{~N}$ & $\mathrm{~N}$ & 6.55 \\
\hline 6 & $4 / 30 / 2018$ & 14:07 & 37.574 & -121.839 & 114.0 & $\mathrm{~N}$ & $\mathrm{~N}$ & 1.03 \\
\hline 7 & $4 / 30 / 2018$ & $13: 39$ & 37.572 & -121.843 & 132.0 & $\mathrm{~N}$ & $\mathrm{~N}$ & 95.69 \\
\hline 8 & $4 / 30 / 2018$ & 10:02 & 37.588 & -121.821 & 45.8 & Y & $\mathrm{N}$ & 120.58 \\
\hline 9 & $4 / 30 / 2018$ & 09:40 & 37.589 & -121.817 & 37.7 & Y & $\mathrm{N}$ & 114.63 \\
\hline 10 & $4 / 30 / 2018$ & $10: 16$ & 37.586 & -121.822 & 43.8 & Y & Y & 49.25 \\
\hline 11 & $4 / 30 / 2018$ & 09:56 & 37.586 & -121.820 & 37.9 & Y & $\mathrm{N}$ & 108.74 \\
\hline 12 & $4 / 30 / 2018$ & 09:52 & 37.586 & -121.818 & 27.7 & Y & Y & 121.32 \\
\hline 13 & $4 / 30 / 2018$ & 09:48 & 37.586 & -121.816 & 20.5 & Y & $\mathrm{N}$ & 139.38 \\
\hline 14 & $4 / 30 / 2018$ & 08:49 & 37.589 & -121.810 & 20.8 & Y & $\mathrm{N}$ & 152.93 \\
\hline 15 & $4 / 30 / 2018$ & 08:54 & 37.589 & -121.811 & 21.3 & Y & Y & 147.61 \\
\hline 16 & $4 / 30 / 2018$ & 08:59 & 37.590 & -121.812 & 24.8 & Y & Y & 161.64 \\
\hline 17 & $4 / 30 / 2018$ & 09:03 & 37.590 & -121.813 & 27.3 & Y & $\mathrm{N}$ & 152.83 \\
\hline 18 & $4 / 30 / 2018$ & 09:26 & 37.591 & -121.815 & 36.1 & Y & $\mathrm{N}$ & 109.01 \\
\hline 19 & $4 / 30 / 2018$ & 09:30 & 37.591 & -121.816 & 28.1 & Y & Y & 20.58 \\
\hline 20 & $4 / 30 / 2018$ & 09:37 & 37.591 & -121.819 & 50.0 & Y & $\mathrm{N}$ & 140.05 \\
\hline 21 & $4 / 30 / 2018$ & 10:10 & 37.589 & -121.822 & 59.8 & Y & $\mathrm{N}$ & 136.95 \\
\hline 22 & $4 / 30 / 2018$ & $10: 28$ & 37.588 & -121.824 & 65.1 & Y & $\mathrm{N}$ & 114.86 \\
\hline 23 & $4 / 30 / 2018$ & $10: 40$ & 37.586 & -121.827 & 75.5 & Y & $\mathrm{N}$ & 113.27 \\
\hline 24 & $4 / 30 / 2018$ & 11:07 & 37.584 & -121.828 & 87.0 & Y & $\mathrm{N}$ & 101.37 \\
\hline 25 & $4 / 30 / 2018$ & $11: 14$ & 37.582 & -121.828 & 86.5 & $\mathrm{~N}$ & $\mathrm{~N}$ & 85.68 \\
\hline 26 & $4 / 30 / 2018$ & $11: 34$ & 37.580 & -121.829 & 92.0 & Y & $\mathrm{N}$ & 87.49 \\
\hline 27 & $4 / 30 / 2018$ & $11: 24$ & 37.580 & -121.829 & 93.4 & Y & $\mathrm{N}$ & 82.96 \\
\hline 28 & $4 / 30 / 2018$ & 11:41 & 37.578 & -121.831 & 100.5 & $\mathrm{~N}$ & $\mathrm{~N}$ & 76.80 \\
\hline 29 & $4 / 30 / 2018$ & $11: 50$ & 37.577 & -121.833 & 107.7 & $\mathrm{~N}$ & $\mathrm{~N}$ & 86.76 \\
\hline 30 & $4 / 30 / 2018$ & 12:01 & 37.575 & -121.835 & 113.8 & $\mathrm{~N}$ & $\mathrm{~N}$ & 74.67 \\
\hline 31 & $4 / 30 / 2018$ & $12: 22$ & 37.573 & -121.837 & 114.1 & $\mathrm{~N}$ & $\mathrm{~N}$ & 77.85 \\
\hline 32 & $4 / 30 / 2018$ & $13: 48$ & 37.571 & -121.840 & 124.4 & $\mathrm{~N}$ & $\mathrm{~N}$ & 75.95 \\
\hline 33 & $4 / 30 / 2018$ & $12: 46$ & 37.570 & -121.842 & 117.8 & $\mathrm{~N}$ & $\mathrm{~N}$ & 78.67 \\
\hline 34 & $4 / 30 / 2018$ & $12: 52$ & 37.570 & -121.845 & 126.0 & $\mathrm{~N}$ & $\mathrm{~N}$ & 60.24 \\
\hline 35 & $4 / 30 / 2018$ & 13:01 & 37.571 & -121.847 & 130.5 & Y & $\mathrm{N}$ & 70.50 \\
\hline
\end{tabular}


Table 6. Bed-material samples particle-size distribution data, San Antonio Reservoir, California.

$[<$, less than; mm, millimeters; \%, percent $]$

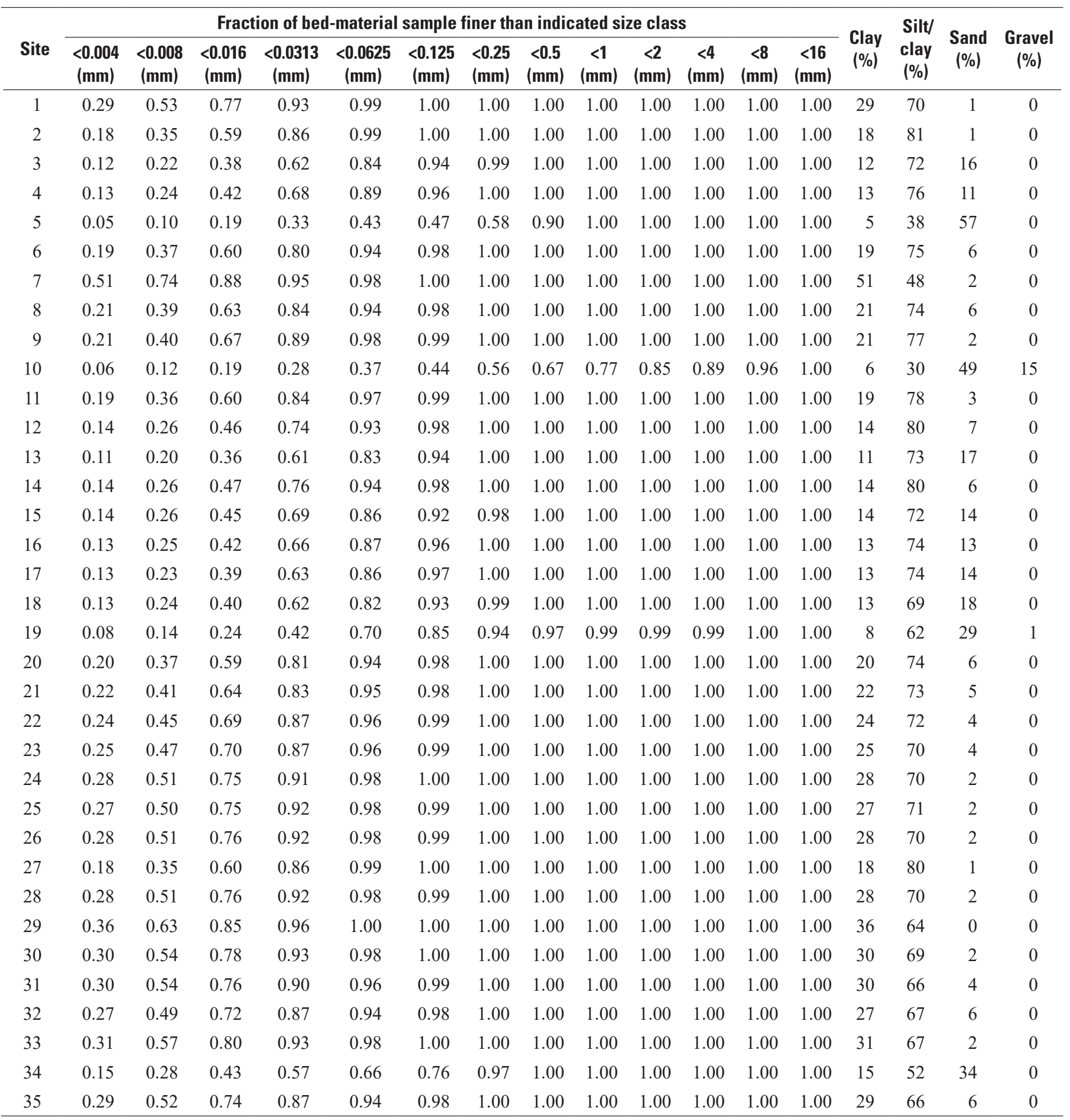




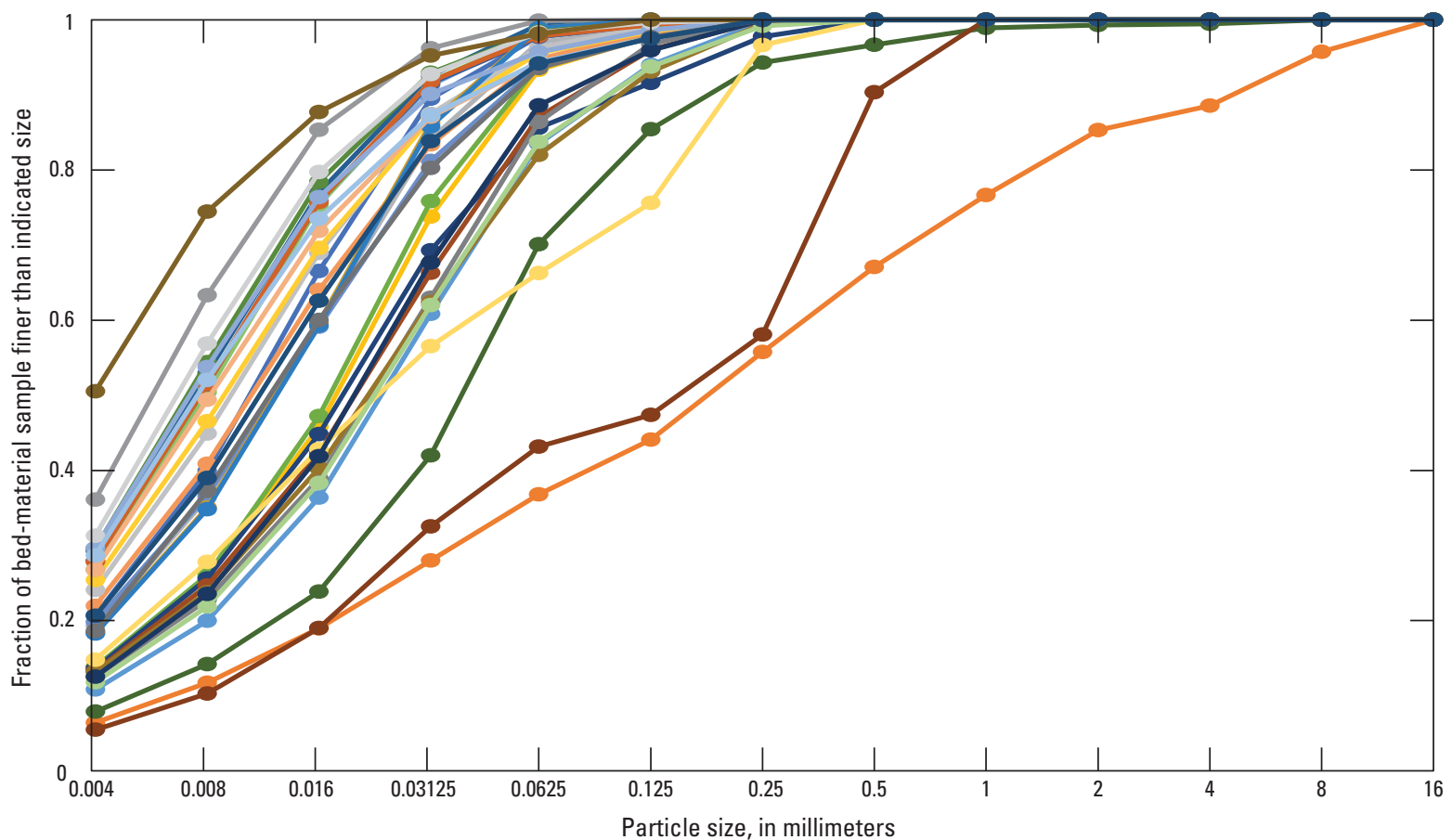

Figure 10. Cumulative particle-size distributions of bed-material samples collected during the April 2018 survey of the San Antonio Reservoir, California.

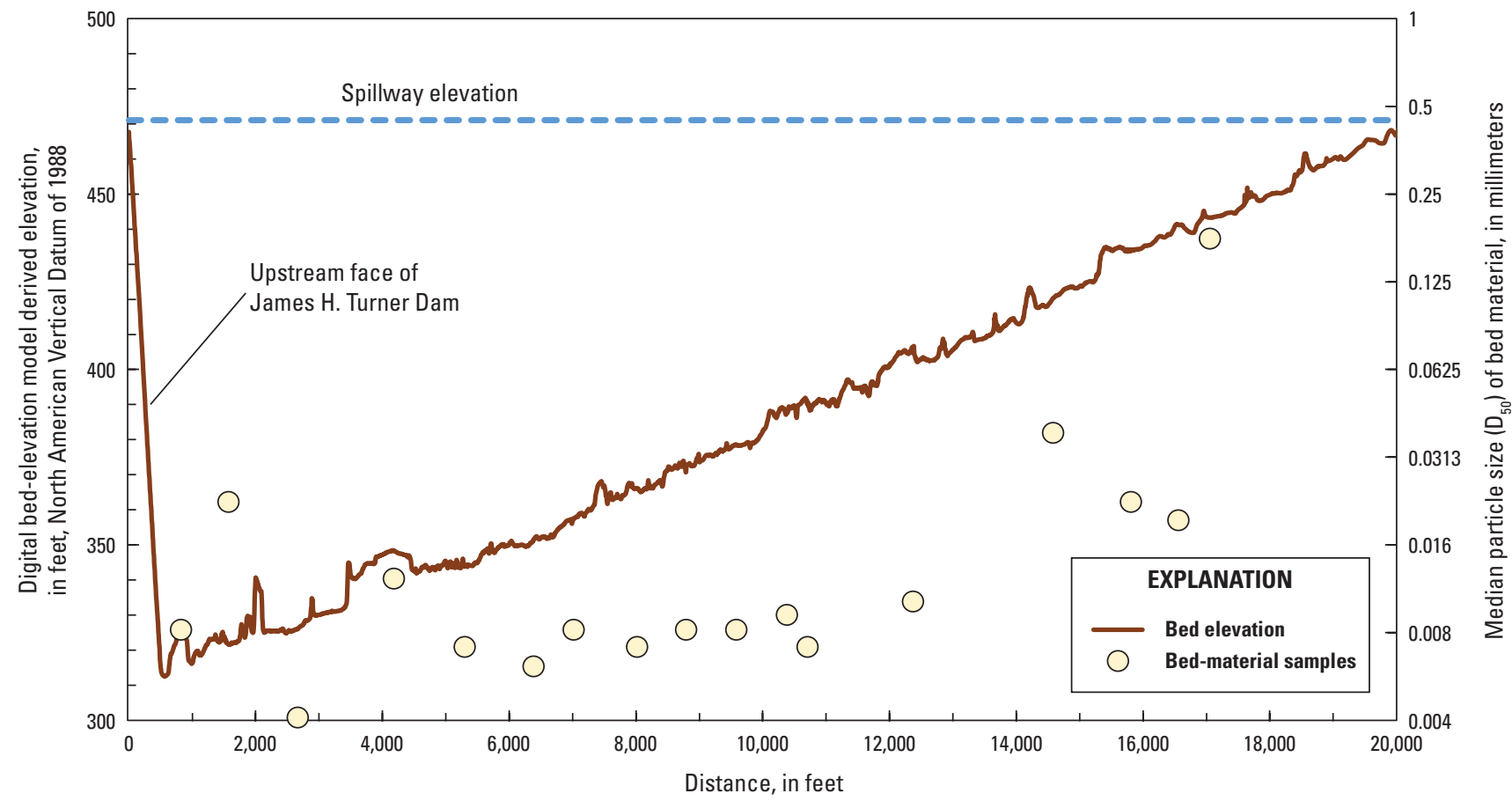

Figure 11. Bed elevation, as extracted from the 2018 digital elevation model (DEM), along the historical (1960) San Antonio Creek centerline, and median particle size $\left(D_{50}\right)$ of bed material from samples projected to the centerline, San Antonio Reservoir, California. 


\section{Discussion of Reservoir Sedimentation}

We were not able to directly calculate rates of overall sedimentation, and thus the loss in storage capacity, due to the uncertainty in the methods used during previous surveys. The total capacity based on the original 1963 pre-construction volume (based on a topographic map) was estimated at 50,500 acre-ft; however, that estimate was based on a 1:17,280-scale topographic map, with contour intervals of $10 \mathrm{ft}$. Map accuracy standards indicate the vertical accuracy of the 1959 topographic model is plus or minus $5 \mathrm{ft}$, thus the uncertainty of the reservoir volume estimated based upon it could be about 4,300 acre-ft. The capacity based on the 2018 survey was 53,266 (5.5 percent greater than the original survey estimate). The differences between the 1994 and 2000 surveys indicate a reduction in capacity of 1.5 percent (Sea Surveyor, Inc., 2000). During those two surveys the respective reservoir levels were not at full capacity. Documentation of horizontal and vertical control for the 2000 survey was incomplete and for the 1994 survey was not available at the time of this publication; therefore, we could not verify if the 1.5 percent change was representative of actual changes in the reservoir capacity or if they were caused by uncertainty or due to errors in survey measurements. Relatively small to negligible sedimentation volumes during a 55-year interval are, however, consistent with the generally intact vegetative ground cover of the San Antonio watershed. Calculating sedimentation rates based on volumetric differences is also sensitive to survey error. In addition, the earlier (1965) estimate of volume was based on 1959 photogrammetry and was not a pre-dam topographic survey.

While analyzing the 2018 bathymetry, the 2018 bathymetric survey DEM was overlaid with a map of the depth-sounding measurements collected in the 2000 survey (Sea Surveyor, Inc., 2000) to identify any areas of sedimentation in the reservoir. There were not any obviously depositional areas observed in the comparison between the 2000 and 2018 surveys, likely due to low-accuracy horizontal and vertical control in the 2000 survey.

As mentioned earlier in this report, the reservoir volume is large in proportion to the size of the watershed $\left(1,410\right.$ acre-ft of storage capacity per square mile [acre-ft/mi' ${ }^{2}$ ] of watershed area). This is because the San Antonio Reservoir serves primarily as an intermediate storage facility for water diverted from Hetch Hetchy Reservoir (located on the Tuolumne River in Yosemite National Park). To put this into context, the median storage capacity to watershed area of 81 other water-supply and irrigation reservoirs in California (with dams at heights of 10 feet or more) was about $515 \mathrm{acre}-\mathrm{ft} / \mathrm{mi}^{2}$ (National Inventory of Dams, 2018). The large storage capacity to watershed area indicates that sedimentation volumes are more likely to be small in comparison to storage capacity (dependent on watershed sediment yield rates). Although we were not able to directly compare the April 2018 bathymetry to previous surveys, we were able to use some of the earlier information to infer changes in the lower (deeper) portion of the reservoir as explained below.

The 1965 and 2018 stage-capacity curves indicate that the lower (deeper) portion of the reservoir appears to have had less storage capacity at the time of this study (733 acre- $\mathrm{ft}$ less storage at $372.7 \mathrm{ft}$ NAVD 88; $370 \mathrm{ft}$ NGVD 29), which could reflect that sedimentation had occurred. The $370 \mathrm{ft}$ NGVD 29 elevation is referenced here because it was the lowest elevation value included in the 1965 stage-capacity relation (fig. 9). The reduced storage capacity in the deeper part of the reservoir agrees with observations of sedimentation in the lower elevation part of the reservoir in which $10 \mathrm{ft}$ of sediment had accumulated over Intake \#1 (fig. 8). At the $372.7 \mathrm{ft}$ NAVD 88 (370 ft NGVD 29) elevation, the surface area of the reservoir is approximately 193 acres. Although it is improbable that sediment deposition would be uniformly distributed in this lower elevation area, 733 acre-ft spread over 193 acres is approximately $4 \mathrm{ft}$ of sediment thickness.

Further inspection of the 1965 and 2018 stage-capacity curves, shows that the upper elevation zone of the reservoir appears to have had greater capacity in 2018 . This could be attributed to displacement of sediment from the upper elevation zones to the deeper zone, uncertainty or error in the early topographic maps, or in part to the smaller uncertainty in the 2018 survey (see the "Survey Error Estimate" section). As mentioned in the "Vertical Datums and Previous Reservoir Surveys" section, the 1965 stage-capacity curve was calculated from a topographic map drawn from 1959 aerial photogrammetry (rather than from topographic survey measurements). Given the complex terrain in parts of the upper elevation zone, it seems likely that the 2018 survey using terrestrial LiDAR produced a more accurate point-cloud model of the rugged terrain, and the 2018 survey represents a more refined volume measurement of those areas. Terrain in the lower elevation zone of the reservoir is not as complex, so the 1965 estimate is likely to be an unbiased approximation of the true storage capacity there. 
Upon closer examination of the lower elevation zone (below $372.7 \mathrm{ft} \mathrm{NAVD} \mathrm{88),} \mathrm{only} 94$ acre-ft of the estimated 2018 survey error applies to the deeper zone. Then it appears that reservoir storage capacity had decreased by about 773 plus or minus 94 acre-ft in 55 years (about 1.5 plus or minus 0.2 percent loss). If correct, this translates to a watershed sediment yield of $0.35 \mathrm{acre}-\mathrm{ft} / \mathrm{mi}^{2}$ per year (or 167 cubic meters per square kilometer $\left[\mathrm{m}^{3} / \mathrm{km}^{2}\right]$ per year). Average sediment yield for watersheds in the Coast Ranges (based on surveys of 23 other reservoirs) was previously estimated to be 417 plus or minus $142 \mathrm{~m}^{3} / \mathrm{km}^{2}$ per year, but can range from 19 to $3,419 \mathrm{~m}^{3} / \mathrm{km}^{2}$ per year (Minear and Kondolf, 2009). The estimates of reservoir sedimentation and basin yield reported by Minear and Kondolf (2009) are volumetric sediment yield values (which are equivalent to the units reported here) rather than sediment yield in mass units. Estimates of the dry weight of sediment would require measurements of density from coring or another empirical method (Lara and Pemberton, 1963). The volumetric sediment yield of $167 \mathrm{~m}^{3} / \mathrm{km}^{2}$ per year that is estimated for the San Antonio watershed is within the range of the previous studies compiled by Minear and Kondolf (2009).

\section{Summary}

The construction of the James H. Turner Dam in 1965 created the San Antonio Reservoir in California. The original capacity of the reservoir was estimated at 50,500 acre-feet (acre-ft) based on a pre-construction topographic map. Since construction of the dam, the bathymetry of the reservoir was surveyed two times: in 1994 and 2000. Those two previous surveys did not include the upper 18 feet (ft) of the reservoir, therefore the San Francisco Public Utilities Commission (SFPUC) could not estimate the full reservoir capacity. To accurately manage reservoir operations, up-to-date reservoir capacity information up to the spillway elevation was needed by the SFPUC. In response, the U.S. Geological Survey (USGS), in cooperation with the SFPUC, conducted a combined bathymetric and topographic survey in April 2018.

Methods were presented for the 2018 collection and analysis of bathymetric and topographic survey data, underwater sound-speed profiles, and bed-material samples. The bathymetric portion of the survey was done using a multibeam echosounder while the shoreline topographic data was collected using a combination of terrestrial Light
Detection and Ranging (LiDAR), and Global Navigation Satellite System-Real Time Network (GNSS-RTN) topographic survey equipment. Approximately 125 kilometers (78 miles) of transects with a total of about 560-million depth soundings and topographic LiDAR points, 500 GNSSRTN topographic survey measurements, 24 sound-speed profiles, and 35 bed-material samples were collected. The depth soundings were corrected for sound-speed gradients, merged with topographic survey points along the shoreline and San Antonio Creek delta, and spatially interpolated to create a bathymetric map of the reservoir in the form of a digital elevation model (DEM). Elevations from the DEM were tabulated to generate the stage-surface area and stagecapacity tables presented in this report. Bed-material samples were analyzed using laser diffraction to obtain particle-size distribution and estimate median particle size.

The results of the April 2018 survey indicate that the reservoir has a capacity of 53,266 acre-ft (plus or minus 140 acre-ft). This represents an increase in measured capacity of 2,766 acre-ft greater than the original reservoir capacity estimate. The increase is likely due to increased accuracy in survey instrumentation and techniques from the 1960s to the present. A comparison of the stage-capacity curves shows a decline in storage capacity in the lower elevation (deeper) part of the reservoir. There also is evidence of sedimentation in that same part of the reservoir. The lowest level intake (Intake \#1) appears to be $10 \mathrm{ft}$ below the bed elevation in that area. The San Francisco Public Utilities Commission reported that Intake \#1 was not operational at the time of this study. Intake \#2 (the second lowest intake) is about $20 \mathrm{ft}$ above the bed in that part of the reservoir, and the live-storage capacity above that intake was estimated at 52,363 acre-ft.

The change in volume between the 1963 pre-construction estimate and the 2018 survey at $372.7 \mathrm{ft}$ North American Vertical Datum of 1988 (370 ft National Geodetic Vertical Datum of 1929) was a decrease of 733 acre-ft. This corresponds to an annual sediment yield of 0.35 acre-ft per square mile (or 167 cubic meters per square kilometer), which is of the same order of magnitude as that found in other watersheds for the Coast Ranges in California. A decrease of 733 acre-ft between 1965 (the year when the dam was fully operational) to 2018 thus represents a loss of 1.5 percent of the overall storage capacity in the reservoir. The result of this survey provides up-to-date stage-surface area and stagecapacity curves to improve reservoir management operations and could serve as a more accurate baseline for monitoring changes in storage capacity in the future. 


\section{References Cited}

Bechtel Corporation, 1963a, San Antonio Dam project reservoir map: San Francisco, Calif., Bechtel, Engineering drawing no. E2994, rev. 2, sheet 3 of 64, scale 1:17280.

Bechtel Corporation, 1963b, San Antonio Dam project outlet works intake structure arrangement: San Francisco, Calif., Bechtel, Engineering drawing no. E3024, rev. 4.

Beckman Coulter, Inc, 2009, LS 13-320 Laser diffraction particle size analyzer instrument manual: Brea, Calif., Beckman Coulter Inc., 246 p., https://www.beckmancoulter. com/wsrportal $/$ techdocs?docname=B05577AB.pdf.

Chen, C.T., and Millero, F.J., 1977, Speed of sound in seawater at high pressures: The Journal of the Acoustical Society of America, v. 62, no. 5, p. 1129-1135, https://doi.org/10.1121/1.381646.

Davis, B.E., 2005, A guide to the proper selection and use of federally approved sediment and water-quality samplers: U.S. Geological Survey Open-File Report 2005-1087, 20 p., https://doi.org/10.3133/ofr20051087.

Dettinger, M.D., Ralph, F.M., Das, T., Neiman, P.J., and Cayan, D.R., 2011, Atmospheric rivers, floods and the water resources of California: Water, v. 3, no. 2, p. 445-478, https://doi.org/10.3390/w3020445.

Digital Globe, Inc., 2018, Satellite image collected March 16, 2016, accessed August 29, 2018, at http://www.digitalglobe.com/.

Edwards, T.K., and Glysson, G.D., 1999, Field methods for measurement of fluvial sediment: U.S. Geological Survey Techniques of Water-Resources Investigations, book 3 , chap. C2, 89 p., https://pubs.usgs.gov/twri/twri3-c2/.

Environmental Systems Research Institute (ESRI) Inc., 2017, ArcGIS version 10.5: Redlands, Calif, Environmental Systems Research Institute Inc.

Idaho State Climate Services, 1999, Köppen climate classification for the conterminous United States: Moscow, Idaho, Idaho State Climate Services, accessed October 22, 2018, at https://catalog.data.gov/dataset/koppen-climateclassification-for-the-conterminous-united-states63aa7.

Johnson Outdoors Marine Electronics Inc., 2014, Description of GPS system: Eufaula, Ala., Johnson Outdoors, accessed June 1, 2016, at https://www.humminbird.com/Category/ Technology/GPS/.
Lara, J.M., and Pemberton, E.L., 1963, Initial unit weight of deposited sediment in Proceedings of the Federal Inter-Agency Sedimentation Conference: Washington, D.C., Agricultural Research Service, U.S. Department of Agriculture, p. 818-848.

Marineau, M.D., Wright, S.A., Lopez, J.V., 2019, Bathymetry, stage-area, and stage-volume tables for the San Antonio Reservoir, California, 2018: U.S. Geological Survey data release, https://doi.org/10.5066/P9KC9DU8.

MathWorks, Inc., 2018, Matlab version R2018a software: Natick, Mass., MathWorks Inc. website, https://www.mathworks.com/help/matlab/release-notesR2018a.html.

Milbert, D.G., 1999, National Geodetic Survey (NGS) height conversion methodology; online documentation for the VERTCON 2.0 datum transformation model: National Geodetic Survey website, accessed November, 6, 2018, at https://www.ngs.noaa.gov/TOOLS/Vertcon/ vert method.html.

Minear, J.T., and Kondolf, G.M., 2009, Estimating reservoir sedimentation rates at large spatial and temporal scales - A case study of California: Water Resources Research, v. 45, no. 12, 8 p., https://doi.org/10.1029/2007WR006703.

National Geodetic Survey (NGS), 2017, The National Adjustment of 2011 Project: National Geodetic Survey website, accessed July 24, 2018, at https://www.ngs.noaa.gov/web/surveys/NA2011/.

National Inventory of Dams, 2018, National inventory of dams - Electronic database of dams for California: National Inventory of dams website, accessed July 18, 2019, at http://nid.usace.army.mil.

National Oceanic and Atmospheric Administration, 2018a, Orthometric height conversion: National Oceanic and Atmospheric Administration website, https://www.ngs.noaa.gov/cgi-bin/VERTCON/vert_con.prl.

National Oceanic and Atmospheric Administration, 2018b, Monthly summaries of climate data for Alameda County: National Oceanic and Atmospheric Administration website, accessed July 24, 2018, at https://www.ncdc.noaa.gov/cdoweb/datasets/GHCNDMS/locations/FIPS:06001/detail.

Norbit, 2018a, Norbit iWBMS quick start guide-TN-1601147.1.0_iWBMS-QuickStart: Norbit, electronic file provided by Norbit, $5 \mathrm{p}$. 
Norbit, 2018b, WBMS iLIDAR user and technical manualTN-160012-24012-7.0.4_WBMS-iLIDAR-manual, 10.3.6 release: Norbit, electronic file provided by Norbit, $26 \mathrm{p}$.

Quality Positioning Services, 2018a, Quality integrated navigation system (QINSy) release 8.18.1 software: Zeist, The Netherlands, Quality Positioning Services website, https://confluence.qps.nl/qinsy/latest/en/qinsy-8-18-1release-77075889.html.

Quality Positioning Services, 2018b, Qimera, release 1.6.1 software: Zeist, The Netherlands, Quality Positioning Services website, https:/confluence.qps.nl/qinsy/latest/en/ qinsy-to-qimera-clean-77076625.html.

Rydlund, P.H., Jr., and Densmore, B.K., 2012, Methods of practice and guidelines for using survey-grade global navigation satellite systems (GNSS) to establish vertical datum in the United States Geological Survey: U.S. Geological Survey Techniques and Methods 11-D1, 102 p. with appendixes, https://doi.org/10.3133/tm11D1.
Sea Surveyor, Inc., 2000, Final report on hydrographic surveys and capacity calculations for six reservoirs: Sea Surveyor, Inc., 4 p.

Trimble, 2013, Trimble access general survey software, version 2.10, revision A: Trimble, 517 p., accessed May 11, 2015, at http://apps.trimbleaccess.com/help/en/ TrimbleAccess $=2013.00$.

Trimble, 2014, Trimble business center software, version 3.40: Trimble, https://geospatial.trimble.com/products-andsolutions/trimble-business-center?gclid=EAIaIQobChMI8ti Q1qyB5QIVhp6fCh16lgVSEAAYAiAAEgKDy_D_BwE. 


\section{Glossary}

Analyzer The Beckman Coulter LS 13-320 Laser Diffraction analyzer, which is used to estimate particle-size distribution of bed-material sediment samples.

CORS Station A Continuously Operated Receiving Station; it is a permanent GPS receiver, which can be used as a base station to make corrections to GNSS survey measurements.

dead storage The volume of storage that lies below the lower-level water outlet and, therefore, cannot be drained through normal dam operations. The dead storage is not usable for water-supply purposes; however, it could be useful for the storage of sediment such that sediment deposition in this region does not decrease the live-storage capacity.

depth soundings Depths sounds (sometimes referred to as soundings or echo soundings) are measurements of underwater depth using ultrasonic sound waves. The depth is calculated based on the travel time for the returning (or reflected) sound wave.

ellipsoid height The height above or below a mathematically defined surface or ellipsoid that provides a representation of the Earth. The height coordinate determined by a Global Navigation Satellite System (GNSS) observation is related to the surface of the ellipsoid and is then converted to an orthometric height using a geoid model.

intake One of the five controlled openings to a large pipe, which can be used to release water to the city of San Francisco's water-supply system.

laser-diffraction particle-size analysis Measurement of particle-size distribution based on light scattering principles. A model is used to determine the distribution of the particles in a sample based on the intensity and angle of the light passed through. Instruments designed for this type of analysis are generally limited to measuring samples with particles ranging from nanometers up to a few millimeters. live storage The volume of storage above the lower-level water outlet, but below the spillway.

monumented benchmark A benchmark used for vertical control and has been permanently marked for easy identification, for example, with a brass circular tablet.

multibeam echosounder An instrument with an array of transducers, which emit and receive sound waves. Distance between the instrument and an underwater object or underwater surface are calculated based on travel time of the returning echo.

orthometric height The height of a point on the Earth's surface measured as a distance along a plumb line and normal to gravity from that point to a geoid.

phi scale A geometric scale based on powers of two and used for measuring sediment particle sizes.

stage-capacity curve A chart or table showing the volume of the reservoir (or capacity) as a function of reservoir stage or water-surface elevation.

stage-surface area curve A chart or table showing the surface area of a reservoir as a function of reservoir stage or water-surface elevation.

terrestrial LiDAR scanner A lidar instrument uses one or more laser beams to measure distance from the instrument to an object or surface based on travel time of the reflected laser beam; terrestrial lidar scanners are near the earth surface (often mounted on a pole) and scan the target area as the scan head either rotates through a large arc about a fixed instrument or transits along a survey line.

vertical sound-speed profile A set of vertical measurements of underwater sound speed collected at different depths. Measurements are collected at uniform time intervals while an instrument is lowered into and raised out of the water. 
For more information concerning the research in this report, contact the Director, California Water Science Center U.S. Geological Survey $6000 \mathrm{~J}$ Street, Placer Hall Sacramento, California 95819 https://ca.water.usgs.gov

Publishing support provided by the U.S. Geological Survey Science Publishing Network, Sacramento Publishing Service Center 


\section{$\frac{\mathbb{2}}{\mathscr{3}}$}

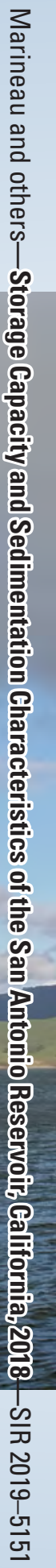

